\title{
Dilemas e agruras na passagem à modernidade: rede de sociabilidade, cultura religiosa e política (Barão do Rio Branco, Oliveira Lima e Gillberto Freyre)
}

\author{
DOI: 10.15175/1984-2503-201810301
}

\author{
Marcia Barros Ferreira Rodrigues ${ }^{\star}$
}

\begin{abstract}
Resumo
Este artigo enfoca os dilemas e agruras presentes no campo intelectual na passagem à modernidade no Brasil por meio da análise da rede de sociabilidade entre José Maria da Silva Paranhos Júnior (Barão do Rio Branco, 1845-1912); Manoel de Oliveira Lima (1867-1928) e Gilberto Freyre (1900-1987). Sublinhamos a permanência histórica de longa duração de ecos da Reforma Protestante no século XVI e do Concílio de Trento (15451563) e as reações da Igreja católica frente às Reformas e suas atualizações históricas na virada do século XIX para o XX. Destacamos a atuação política e intelectual do Barão do Rio Branco, Oliveira Lima e Gilberto Freyre como desdobramentos desse debate e campo de disputa. A pista que nos interessa interpretar a partir desta perspectiva, é a ambivalência e contradição entre o pensar, o sentir e o agir dos personagens históricos em suas ações, e analisar a natureza complexa da cisão: teológica, ideológica, política e psicológica provocada por este "cisma". O tema proposto será tratado numa interpretação interdisciplinar norteada pelas Ciências Sociais, em particular a Sociologia Política, e a História na denominação de "história subjetivada", que implica uma escuta atenta das emoções, muitas vezes inconscientes, inscritas no acontecer social que podem produzir efeitos de registro traumático e sofrimento psíquico.
\end{abstract}

Palavras-chave: Rede de sociabilidade; cultura religiosa; cultura política; subjetividade; relações de poder.

Dilemas y penurias en la transición a la modernidad: red de sociabilidad, cultura religiosa y política (Barón del Río Branco, Oliveira Lima y Gillberto Freyre)

\section{Resumen}

Este artículo aborda los dilemas y penurias presentes en el campo intelectual en la transición a la modernidad en Brasil por medio del análisis de la red de sociabilidad entre José Maria da Silva Paranhos Júnior (Barón del Río Branco, 1845-1912); Manoel de Oliveira Lima (1867-1928) y Gilberto Freyre (1900-1987). Subrayamos la permanencia histórica de larga duración de ecos de la Reforma Protestante en el siglo XVI y del Concilio de Trento (1545-1563), y las reacciones de la iglesia católica a las reformas y sus actualizaciones históricas en el paso del siglo XIX al XX. Destacamos la actuación política e intelectual del Barón del Río Branco, Oliveira Lima y Gilberto Freyre como desdoblamientos de ese debate y campo de disputa. La pista que nos interesa interpretar a partir de esta perspectiva es la ambivalencia y contradicción entre el pensamiento, el sentimiento y la actuación de los personajes históricos en sus acciones, con intención de analizar así mismo la naturaleza compleja de la escisión: teológica, ideológica, política y psicológica provocada por este «cisma». El tema propuesto será tratado en una interpretación interdisciplinaria comandada por las ciencias sociales, en particular la sociología política, y la historia en la denominada «historia subjetiva», que implica una percepción atenta de las emociones, muchas veces inconscientes, inscritas en el devenir social que pueden tener consecuencias en el registro traumático y el sufrimiento psíquico.

\footnotetext{
* Professora Titular de Sociologia da Universidade Federal do Espírito Santo. Doutora em História Social pela Universidade de São Paulo. Pós-doutorado em Ciência Política pela Universidade Federal Fluminense. Professora do Programa de Pós-Graduação em Ciências Sociais da Universidade Federal do Espírito Santo. Coordenadora do Núcleo de Estudos Indiciários (NEI), Pesquisadora do CNPq, da Fundação de Amparo à Pesquisa do Espírito Santo (FAPES) e membro efetivo da Associação Universitária de Pesquisa em Psicopatologia Fundamental (AUPPF). E-mail: mbfrodrigues@gmail.com
} 
Palabras clave: Red de sociabilidade; cultura religiosa; cultura política; subjetividade; relación de poder. Dilemmas and hardships in the transition to modernity: Sociability network, religious and political culture (Barão do Rio Branco, Oliveira Lima and Gilberto Freyre)

\section{Abstract}

The following article considers the dilemmas and hardships experienced by the intellectual field during Brazil's transition to modernity by analyzing the sociability network between José Maria da Silva Paranhos Júnior (Baron of Rio Branco, 1845-1912), Manoel de Oliveira Lima (1867-1928), and Gilberto Freyre (1900-1987). We highlight the long-term historical permanence of echoes of the Protestant Reform in the sixteenth century and the Council of Trent (1545-1563), as well as the Catholic Church's reactions to the Reforms and their historic reworkings at the turn of the twentieth century. We also discuss the political and intellectual activities of the Baron of Rio Branco, Oliveira Lima, and Gilberto Freyre as ramifications of this debate and the field of dispute. Our starting point of interpretation within this perspective is the ambivalence and the contradictions inherent to these historical figures' thoughts, feelings, and actions, spurring an analysis of the complex nature of the theological, ideological, political, and psychological split provoked by the "schism". The subject proposed will be handled according to an interdisciplinary interpretation guided by the Social Sciences, particularly Political Sociology, and History in the defining of "subjectified history". This entails a close consideration of the often-unconscious emotions involved in the social sphere, which may produce traumatic effects and psychological suffering.

Keywords: Sociability network; religious culture, political culture; subjectivity; relations of power.

Dilemmes et aigreurs lors du passage à la modernité : Réseau de sociabilité, culture religieuse et politique (Barão do Rio Branco, Oliveira Lima et Gilberto Freyre)

\section{Résumé}

Cet article s'intéresse aux dilemmes et aux aigreurs présents dans le champ intellectuel lors du passage à la modernité au Brésil, moyennant l'analyse du réseau de sociabilité existant entre José Maria da Silva Paranhos Júnior (Barão do Rio Branco, 1845-1912), Manoel de Oliveira Lima (1867-1928) et Gilberto Freyre (19001987). Nous soulignerons ici la permanence historique de longue haleine des échos de la réforme protestante du XVle siècle et du Concile de Trente (1545-1563), ainsi que des réactions de l'église catholique face aux réformes et à leur mise à jour historique au tournant du XXe siècle. Nous nous intéresserons particulièrement au rôle politique et intellectuel du Baron de Rio Branco, d'Oliveira Lima et de Gilberto Freyre en tant que conséquence de ces débats. La voie que nous souhaitons suivre à partir de cette perspective est celle de l'ambivalence et de la contradiction entre le penser, de sentir et l'agir dans l'action des personnages historiques, en vue d'analyser la nature complexe de la scission théologique, idéologique, politique et psychologique provoquée par ce « schisme ». Le thème proposé sera traité dans le cadre d'une interprétation interdisciplinaire orientée par les sciences sociales, et en particulier par la sociologie politique et l'histoire dans sa modalité « histoire subjectivée ", qui implique une écoute attentive des émotions, souvent inconscientes, inscrites dans les événements sociaux et qui peuvent produire des effets de nature traumatique et psychique. Mots-clés : réseau de sociabilité ; culture religieuse ; culture politique ; subjectivité ; rapports de pouvoir.

\section{通往现代之路的困境与阻隔：社交网络, 宗教和政治文化 ( 里奥布兰科男爵, 奥利维拉·利马和吉尔伯托·弗莱雷) 摘要}

本文主要讨论巴西现代知识分子在通往现代化进程中所遭遇的困境和阻碍。我们将通过分析三代著名知识分 子 的社交网络来验证我们的观点。这三代知识分子是里奥布朗库男爵(José Maria da Silva Paranhos Júnior, 1845-1912), 奥利维拉·利马 (Manoel de Oliveira Lima, 1867-1928) 和吉尔伯托·弗莱雷 (Gilberto Freyre 19001987)。我们讨论十六世纪的宗教改革，特兰托的教廷会议(1545-1563) 对历史进程所产生的长期 (longa duração)影响, 以及天主教会的应变改革措施, 及其在十九世纪末到二十历史初期的表现。我们强调里 奥布兰 科男爵, 奥利维拉·利马和吉尔伯托·弗莱雷的政治和思想活动都是在此背景下所展开的, 他们遭遇的困 境和阻 隔都是“宗教改革与天主教反制”这一长期历史冲突中的产物。从这个角度解释这条现代化之路, 我们指 出这些 知识分子所遭遇的困境, 他们的思想与行动之间的矛盾, 感情和行为的冲突, 分析了这些“分裂”的复杂 性。我 们运用神学 , 思想史 , 政治和心理学方法来分析这种“分裂”。我们从“历史主观性”角度来倾听三位知识 分子的 意识和潜意识, 以及他们的焦虑情绪, 这种意识与情绪在社交事件中会有所体现, 并常常会引起冲突, 从而 产生创伤记忆和心理痛苦。

关键词：社交网络；宗教文化；政治文化；主体性；权力䏍系。 
Passagens. Revista Internacional de História Política e Cultura Jurídica

Rio de Janeiro: vol. 10, n⿳30, setembro-dezembro, 2018, p. 335-367.

O eixo da discussão que proponho analisar nesse artigo são os dilemas e agruras presentes na passagem à modernidade no Brasil por meio da análise do "prolongamento geracional que identifica Gilberto Freyre como "homem ponte" entre o grupo-geração de Oliveira Lima e o seu próprio" (MOTA, 2010, p. 86ª). ${ }^{1}$ Isto inclui investigar a rede de sociabilidade entre José Maria da Silva Paranhos Júnior (Barão do Rio Branco 1845-1912); Manoel de Oliveira Lima (1867-1928) e Gilberto Freyre (1900-1987). Especificamente a pista que me interessa interpretar é a concepção de equilíbrio dos antagonismos formulada por G. Freyre (1933, ${ }^{\mathrm{a}} 2006^{\mathrm{a}}$ ) em Casa Grande \& Senzala $(C G \& S)^{2}$ como herança intelectual da geração de Oliveira Lima e posteriormente do barão do Rio Branco vivida como missão, no sentido religioso, ou seja, como dever. Inclusive para sermos mais exatos as raízes dessa concepção são prolongamentos históricos de longa duração no campo católico jesuíta expressas por São Tomaz de Aquino. Destacaremos a pertinência da concepção de equilíbrio dos antagonismos à ideologia do favor e os efeitos políticos e epistemológicos desta marca indelével da sociedade brasileira expressa por uma "ignorância simbólica da Lei" tal como formula Cerqueira Filho (1993). ${ }^{\text {a }}$

A abordagem parte da perspectiva filogenética psicopatológica da humanidade cunhada por Freud e que tem influência de longa duração na Psicopatologia e, particularmente, na Psicopatologia Fundamental (BERLINCK, 2000). ${ }^{\text {a }}$ Inscreve-se no campo e estudos da Psicopatologia Fundamental sem, no entanto, fundamentar-se na clínica ou na experiência psicoterapêutica, mas naquilo que Lacan denominou de clínica em extensão, ou psicanálise em extensão, ou seja, a Escola nas suas incursões pelo mundo (circularidade das ideias) e as tensões aí inseridas. ${ }^{3}$ Portanto, o tema será tratado numa interpretação interdisciplinar norteada pelas Ciências Sociais, em particular a

\footnotetext{
${ }^{1}$ Este artigo faz parte das pesquisas e discussões sobre Vulnerabilidade Psíquica, Poder e Teoria Política do Laboratório Cidade e Poder/Universidade Federal Fluminense em parceria com o NEI - Núcleo de Estudos e pesquisas Indiciárias da Universidade Federal do Espírito Santo. Este texto foi produzido originalmente como parte das atividades desenvolvidas nos estudos e pesquisas de Pós-Doutorado na Universidade Federal Fluminense (UFF) em 2016, sob a supervisão Da Profa. Dra. Gizlene Neder e do Prof. Dr. Gisálio Cerqueira Filho junto ao Programa de Pós-Graduação em Sociologia e Direito (PPGSD) e no Laboratório Cidade e Poder (LCP) da referida universidade. Os desdobramentos do tema integram também a pesquisa que realizo na Associação Universitária de Pesquisa em Psicopatologia Fundamental (AUPPF).

${ }^{2}$ A partir de agora iremos nos referir a obra de Gilberto Freyre, Casa Grande \& Senzala pela sigla CG\&S

${ }^{3} \mathrm{~A}$ pesquisa acadêmica em psicanálise versus a psicanálise estrito senso (clínica) jogam com a ambivalência e a tensão de duas expressões cunhadas por J. Lacan, "psicanálise em extensão" (a Escola nas suas incursões no mundo) e "psicanálise em intensão" (a formação de operadores, o que sugere a singularidade da experiência [clínica] psicanalítica). A homofonia das palavras em francês intention (intenção) e intention (com o sentido denotativo de tensão) apostam na in-tensão da ambivalência do próprio saber psicanalítico. Com o método clínico ocorreria algo similar (CERQUEIRA FILHO, 2009, p.1). ${ }^{a}$
} 
Sociologia Política, e a História na denominação de "história subjetivada", que implica uma escuta atenta das emoções, muitas vezes inconscientes, inscritas no acontecer social que podem produzir efeitos de registro traumático e sofrimento psíquico.

A contribuição para o debate é da constituição de uma experiência, um discurso compartido a respeito do pathos psíquico (sofrimento-paixão) a partir da relação entre pathos, cultura, poder e política entendendo que o pathos constitui uma subjetividade que é expressão de uma história singular e coletiva simultaneamente. Para tal, o discurso de Freyre será analisado a partir de CG\&S. ${ }^{4} \mathrm{~A}$ obra tornou-se referência da identidade nacional brasileira e expressão do processo de constituição de uma civilização nos trópicos baseada na concepção de miscigenação por mistura e no equilíbrio dos antagonismos oferecendo pistas de um padrão ideológico alicerçado na ideologia do favor. A miscigenação por mistura pressupõe um padrão de pureza onde a violência e o sofrimento (pathos) se diluem na construção mitológica e epopeica freyriana, porém não desaparece, permanece latente. Ao narrar de forma fabulosa à formação de uma civilização nos trópicos por meio do ethos da cultura brasileira, Freyre denega o sofrimento e ao fazê-lo reintroduz o mal-estar, sem o querer, ou saber. Desta feita, é importante investigar o conjunto das injunções históricas e sociais juntamente com as motivações político-afetivas e/ou subjetivas que levaram Gilberto Freyre a construir tal interpretação envolvendo o campo intelectual e trajetórias do grupo-geração: Oliveira Lima - Barão do Rio Branco. Para tal, não separamos obra e vida dos intelectuais, portanto, metodologicamente as correspondências entre eles serão tomadas como extensão da sua produção intelectual, assim como artigos no jornal, diários e memórias. A premissa é de que não é a condição de intelectual que desencadeia uma estratégia de sociabilidade, mas ao contrário, é a participação numa rede de contatos que demarca a específica inserção no mundo cultural. A produção do intelectual é demarcada por "lugares de sociabilidade que podem ser marcados por práticas culturais de oralidade e ou escrita envolvendo ideias, projetos, opiniões, interesses e sentimentos" (GOMES, 2005, p.12-13). ${ }^{a}$ Dessa forma, a intenção é buscar uma aproximação das formas de

\footnotetext{
${ }^{4}$ A escolha não foi aleatória, se deu em função da importância da obra no imaginário social brasileiro e sua repercussão no exterior quando de sua publicação e a posteriori. Gilberto Freyre recebeu elogios de Braudel, Barthes, Tannenbaum, para citar alguns. A importância de sua obra é tanta, diz Tannenbaum (1963, p. VII), ${ }^{a}$ que, no futuro, a história do Brasil será dividida "em duas partes: antes e depois de Gilberto Freyre"; a obra

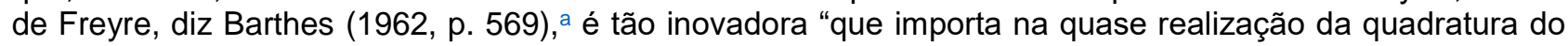
círculo dos historiadores, o ponto último da investigação histórica". Braudel, que afirmara ser Freyre "o mais lúcido dos escritores brasileiros", o colocava ao lado de outros autores importantes e explicava a relevância de seus livros a seus alunos da Sorbonne (cf. depoimento de Marc Ferro apud DAIX, 1995, p. 220). ${ }^{\text {a }}$ A editora Gallimard apresentou a edição francesa de Casa-Grande \& Senzala como "livro da mesma categoria de Guerra e Paz, de Tolstoi".
} 
estruturação do campo intelectual e político da conjuntura, possibilitando a investigação da maneira de produção e implicações epistemológicas e político-afetivas concernentes aos dilemas entre esses grupos e gerações.

A chave de interpretação que orienta esta análise concebe que o ideal de perfeição tal qual foi formulado na Idade Média (tomismo) deslizou para as ciências sociais e como consequência, o ideal de perfeição e a ideia de normalidade considerou a emoção como uma interferência indesejável. Entretanto, entendo que o afeto é político e assim me afasto da perspectiva positivista e do projeto iluminista com sua tecnologia focada na atenção dirigida na qual o sujeito se dissocia do objeto. Adoto a perspectiva do paradigma indiciário (GINZBURG, 1989) ${ }^{a}$ e a escuta psicanalista em contraposição ao dualismo interpretativo na busca da relação dialética e dialógica entre o sujeito e objeto incluindo os afetos expressos por emoções contidas nos discursos tomados como peça analítica.

A perspectiva histórica desta interpretação se orienta pelas teses de Gizlene Neder

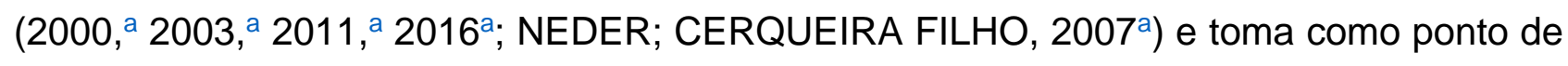
partida a Reforma Protestante no século XVI e o Concílio de Trento (1545-1563) e as reações da Igreja católica frente à Reforma e as dissidências no seu campo. Nesse contexto emergem debates calorosos entre duas tendências teológicas e políticas do campo católico, a saber, o jansenismo e o jesuitismo, com prolongamentos expressos no neotomismo na virada do século XIX para o XX. O recorte temporal é o debate teológico estendendo-se ao político entre o jansenismo, tendência dissidente da lgreja Romana e o jesuitismo, vertente oficial do vaticano desde Leão XIII (1878-1903) e suas repercussões no Brasil na passagem à modernidade. Nesse sentido, entendo que a atuação política e intelectual do Barão do Rio Branco, Oliveira Lima e Gilberto Freyre são desdobramentos desse debate e campo de disputa e desde já esclareço que não me interessa o debate religioso ou teológico propriamente dito, mas as repercussões ou os deslizamentos dessas ideias para o campo político. O jansenismo e o combate que lhe moveram o jesuitismo e forças ligadas ao papado abriram um conflito vivido por intelectuais em relação à fé e a ciência na Europa, particularmente em Portugal e França e também no Brasil. Em síntese, o combate do jesuitismo e do papado ao jansenismo provocou conflitos em relação à fé em alguns intelectuais no âmbito da obediência ao papa e/ou as regras da investigação científica. Esse dilema foi vivenciado por Blaise Pascal, um dos maiores investigadores científicos de seu tempo, na vanguarda da física e da matemática. E no Brasil, por Paulo Merêa e Teixeira de Freitas, entre outros (NEDER; CERQUEIRA FILHO, 2007, ${ }^{\mathrm{b}} 2011^{\mathrm{b}}$ ).

Acompanhando esse argumento Coelho (2016, p. 38, grifo nosso ${ }^{\mathrm{a}}$ ressalta que: 
Passagens. Revista Internacional de História Política e Cultura Jurídica

Rio de Janeiro: vol. 10, n⿳30, setembro-dezembro, 2018, p. 335-367.

A estrutura política francesa não aceitava o monopólio da Igreja de Roma em seu território [...]. Desta feita, fortaleceu-se a tendência separatista da Igreja Católica da França em relação a Roma e ao Papa, estabelecendo limites ao poder papal e maior autonomia político-religiosa local. Esta tendência ficou conhecida como galicanismo. Muito embora sejam movimentos católicos distintos, o jansenismo e $o$ galicanismo possuem afinidades, entre as quais, a contestação do autoritarismo político da Igreja de Roma, principalmente, em sua expressão jesuítica [...]. Para interpretarmos o jansenismo no Brasil teremos que pensá-lo a partir de Portugal, pois forças antagônicas e dinâmicas no interior do próprio catolicismo, que agiram e reagiram na Europa, assumiram características particulares em diferentes regiões. Desta feita, o jansenismo que se alastrou no Brasil foi reflexo do modelo português [...]. O clero que aqui se instalou recebeu maior interferência dos jesuítas, no entanto, nunca formou uma unidade religiosa homogênea, ao contrário, como na Europa, viu-se atravessado por disputas entre ordens e congregações. Disputas religiosas com efeitos políticos, que foram sobredeterminados por interesses da Igreja no Brasil, do Reino e de Roma. O padroado estabeleceu relações de dependência entre o Estado e o papado, que se configuraram como reciprocidade e interferências entre lgreja e governo. Também engendrou apadrinhamentos e favorecimentos. Este pacto tornou-se uma matriz político-religiosa determinante da consolidação de uma ideologia do favor, de longa duração, na formação do Brasil.

Assim, apesar do "silêncio da Igreja Romana sobre o 'cisma' [...] e, mesmo considerando que, aparentemente, os pascalinos tenham sido derrotados, os efeitos políticos e epistemológicos decorrentes do cisma ainda se fizeram presentes no século XX, e além" (NEDER; CERQUEIRA FILHO, 2011, p. 103). . Desse modo, me interessa discutir a partir desta perspectiva, as ambivalências e contradições entre o pensar, o sentir e o agir dos personagens históricos em suas ações e analisar a natureza complexa da cisão: teológica, ideológica, política e psicológica provocada por este "cisma". A ideologia tomista da terceira escolástica deve ser tomada como sintoma entendido não como uma simples mensagem cifrada, mas como um meio do sujeito organizar o seu gozo e, portanto, constantemente reeditado.

Isto posto, destaco que os elementos preliminares desta análise foram instigados pelas reflexões de Berlinck et al (2001) a em “Esquizofrenia e Miscigenação" e pelo texto de Freud (1914/1987) a Neuroses de Transferência: uma síntese. Tomando essas reflexões como base, temos que o projeto "civilizatório e moderno" de colonização do Brasil pode ser entendido como um ataque virulento contra as populações autóctone produzindo uma insuficiência imunológica psíquica ${ }^{5}$ (BERLINCK, 2000) ${ }^{\mathrm{b}}$ que, por sua vez, se relaciona com

\footnotetext{
${ }^{5}$ Nossa subjetividade se construiu apoiada no medo do extermínio provocado por uma insuficiência imunológica psíquica que Berlinck denomina de um desamparo adicional que, como uma paixão, um gozo, expõe o sujeito a um extermínio. Esse desamparo adicional é uma estranha forma de manifestação da subjetividade humana. Essa insuficiência ou incapacidade de se proteger contra-ataques virulentos exteriores habita o imaginário ocidental alicerçado num mito das origens da subjetividade humana e pode ser relacionada com a colonização ocidental nas Américas.
} 
as fantasias fabulosas presentes nesse processo e, por fim, com a interpretação mitopoética epopéica formulada por Gilberto Freyre em CG\&S.

Seguindo até certo ponto a pista de Calligaris (2000) a que aponta a falta do Um no Brasil a partir da expressão: Esse pais não presta! Ou seja, os brasileiros podem falar do Brasil como se fossem estrangeiros, ou seja, de fora, "porque de alguma maneira o Um de suas diferenças seria um traço identificatório fundante da filiação nacional”. Destaco a pergunta instigante que Calligaris $\left(2000\right.$, p. 15) ${ }^{\mathrm{b}}$ se faz: "Como funciona então um significante nacional que permite que quem se reclama dele enuncie: Esse país não presta?" A conclusão de Calligaris (2000, p. 17), ${ }^{c}$ é que a "suma ou o Um nacional na sua instituição parece ter sido proposto ao colono não como valor simbólico implicando ser reconhecido e se reconhecer, mas como marca de uma potência exploradora". Falta filiação, não há pai no Brasil e isso abre porta para o gozo sem limite sem interdição, expressão trágica do recalque do desejo que tem sua verdade num passado esquecido, a saber, a colonização. Ora, retomando meu argumento, saliento que o sofrimento (pathos) embutido nas perguntas feitas por Freyre em CG\&S, não vieram à tona nas suas respostas. Nesse sentido, CG\&S ao tomar como missão uma saída salvífica para o Brasil em relação à miscigenação e revisitar e interpretar o passado "esquecido" denega-o. Desta feita, Freyre a partir de Oliveira Lima, remonta as origens ibéricas da nossa formação e a figura onipresente e idealizada do pater, senhor de terras, que tudo pode e tudo quer. Nessa operação, sem o saber ou querer, não importa, traz à tona o tema tão caro à psicanálise proposta por Freud na interpretação da cultura e das origens da subjetividade humana, a saber, a morte do pai e a instauração do conflito edipiano. Nessa direção, concordo com as reflexões sobre a instauração do conflito edipiano de Carl Schorske (1988, p. 194)a quando assinala que Freud em Totem e Tabu "prenunciava sua teoria política madura, cujo princípio central é que toda a política é redutível ao conflito originário entre pai e filho".

Vejamos estas passagens em Freyre. Que cada um fique "o mais possível no lugar onde nasceu. Nada de muita emenda ao soneto da vida”, diz Freyre (1975, p. 192), ${ }^{a}$ já de volta ao Brasil em 1923. Quando ainda em Nova lorque, mas aspirando produzir uma obra interpretativa da cultura brasileira, ele afirma que só se considera capaz de compreender profundamente seu próprio país. "É a terra brasileira que me considero com o direito de possuir plenamente, completamente, como um macho a uma fêmea, com todas as forças

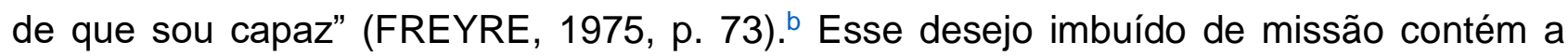
questão edipiana via interpretação da formação de uma civilização nos trópicos em CG\&S. Reedita a partir da narrativa dos excessos e da "solução" pelo equilíbrio dos antagonismos, 
nosso sintoma, ou seja, a falta de um significante paterno, ou Nome-do-Pai no dizer de Jacques Lacan (2009a). ${ }^{6}$

Avançando na análise com Cerqueira Filho $(1993)^{\mathrm{b}}$ que oferece uma abordagem que vai além de Calligaris, temos o destaque para a presença na formação social brasileira da ideologia do favor e do arbítrio contido na sua configuração naquilo que o autor nomeia de ignorância simbólica da lei. Ausência/degradação da figura paterna e do não reconhecimento da lei jurídica com efeitos perversos na construção da cidadania no Brasil. O fundamento da teoria de Gisálio neste livro é forjar um pensamento capaz de articular a representação da lei jurídica com a representação da lei no sentido psicanalítico. A ignorância simbólica da lei versus a questão da cidadania (Ciência Política) - Dupla função paterna repressiva/transgressiva (Psicanálise). Dessa maneira, enfatizo que na problemática em questão as injunções são de ordem política, conjuntural, ideológica e subjetiva e concordo com as hipóteses levantadas pelo autor.

Hipótese 1: A presença acentuada de práticas de favor integradas à instituições servis e semi-servis, aliada à forte diferenciação cultural (indígena e africana) traduziu-se no bloqueio da concepção ideológica de uma "sociedade de indivíduos" apoiada na tradição do pensamento burguês. Portanto, a fundação do imaginário social brasileiro tem como fio condutor a tensão entre liberalismo e ideologia do favor via tomismo. Os efeitos ideológicos dessa hipótese são o recalcamento da lei no plano simbólico; a política vista de forma desqualificada (como farsa) - pensada como uma prática inscrita no âmbito da manipulação, corrupção, como uma prática imoral; a política vivida de forma positiva (como missão), sentida como missão salvífica, que moralizará as relações de poder. Hipótese 2. A tensão existente entre a ideologia do favor e o liberalismo implica no recalcamento da concepção jurídica de lei no imaginário social. Hipótese 3. O nome do Pai. A ignorância simbólica da lei, a nível inconsciente, resulta de uma complexa operação, onde incidem a carência da figura paterna ou a presença de uma figura paterna degradada (CERQUEIRA FILHO, 1993, p. 19-36). ${ }^{c}$

\footnotetext{
${ }^{6}$ No Seminário, Livro III e à luz da clínica das psicoses, Lacan conduz à noção do Nomedo-Pai como significante da Lei. No percurso dos seus ensinamentos a noção o Nome-do-Pai, inicialmente é a sustentação da ordem simbólica portadora da interdição, até chegar à sua função de "sinthoma". Do pai inicial, fundamento do laço social reduzido a um símbolo, portanto na condição de morto, chegaremos a um pai vivo; da unicidade a uma multiplicidade de "exceções" à lei; da universalidade à particularidade do objeto a que um homem extrai do corpo de uma mulher. O Nome-do-Pai multiplica-se em tantos nomes quantos forem os suportes à sua função. Em sua última apresentação, comparece como maneira de ligar os três registros (real, simbólico, imaginário), que cada pai realiza como homem em relação a uma mulher e que decorre da maneira particular pela qual um pai pode suprir uma não relação sexual.
} 
Passagens. Revista Internacional de História Política e Cultura Jurídica

Rio de Janeiro: vol. 10, n⿳3 s, setembro-dezembro, 2018, p. 335-367.

A consistência dessas hipóteses norteadoras desta a análise permite identificar em CG\&S, escrito no decorrer da década de 1920 e publicado em 1933, o prolongamento geracional de um dilema vivido pela geração anterior em relação à identidade nacional e a questão racial na passagem à modernidade. Um "problema" a ser revolvido pela "missão salvífica" embalada pelo desejo de pertencer aos padrões europeus de "civilidade e pureza", a despeito do mal-estar causado pelo passado escravocrata e da expressiva população composta de negros e mestiços. Assim, sustento que a "saída" apresentada por Freyre em CG\&S, a despeito de ser original, foi gestada por seu "pai" intelectual e amigo Manoel de Oliveira Lima, que por sua vez pertencia ao círculo do Barão do Rio Branco e que se inspira nas raízes do passado colonial ibérico e medieval.

Neste ponto, os desdobramentos oferecidos por Cerqueira Filho (2002) ${ }^{\mathrm{a}} \mathrm{em}$ "Olho grande ou o olhar da inveja na política", nos oferece indícios valiosos a partir de Baltasar Gracián (1601-1658), teólogo tomista que introduz em sua obra uma discussão importante sobre o sentimento da inveja e as fantasias que the são correlatas. ${ }^{7}$ Para além de Maquiavel, que aponta a prudência da arte como virtú na política; Gracián relaciona em contraponto a política encarnada como prudência (arte) em contradição com a percepção tomista da política como missão (vocação). Arte em contraposição a vocação. A reflexão de Garcián tem como foco uma estratégia que visa driblar, enganar a imagem esculpida com base na idealização narcísica que é capaz de provocar, despertar no Outro o ódio e a inveja (CERQUEIRA FILHO, 2002, p. 80). ${ }^{\text {b }}$ Nesse sentido, o filósofo Slavoj Zizek acrescenta uma contribuição para pensarmos os efeitos perversos quando a inveja vira ódio, ou seja, quando a frustração e a inveja se radicalizam, dando lugar a um ódio autodestrutivo podendo desencadear vingança violenta. ${ }^{8}$ No entanto, no caso em questão interessa reter para análise das relações entre O Barão do Rio Branco, Oliveira e G. Freyre, os paradoxos, as contradições, as perplexidades, as ambivalências do sentir/pensar/agir que ilumina 0 mote lacaniano $\mathrm{O}$ eu é um Outro, análogo ao que Gracián denomina "a montra" (vitrine,

\footnotetext{
7 Ver do autor o conjunto das obras El beros, 1637, El político, 1640, El discreto, 1646 e Oráculo manual y arte de prudência, 1647. Com exceção do último todos os livros foram escritos sob o pseudônimo de Lorenzo Gracián, um dos seus irmãos, e Garcia de Marlones, um anagrama.

${ }^{8} \mathrm{O}$ vício primário de uma pessoa perversa é preocupar-se mais com os outros que com ela mesma. Segundo

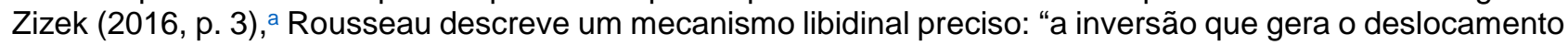
do investimento libidinal do objeto para o próprio obstáculo. Ou seja, esse potencial destrutivo da inveja é à base da conhecida distinção traçada por Rousseau em 'Diálogos ou Rousseau Juiz de Jean-Jacques' entre o egotismo, 'amour-de-soi', o amor de si mesmo (o amor por si próprio que é natural), e o 'amour-propre', amor-próprio, a preferência pervertida por si mesmo em detrimento dos outros, em que a pessoa se concentra não tanto em alcançar uma meta, mas em destruir o obstáculo que se interpõe a ela: a frustração e a inveja se radicalizam, dando lugar a um ódio assassino e autodestrutivo, e as pessoas buscam a vingança violenta".
} 
exposição), ou seja, o alimento com o qual a inveja deve nutrir-se: a montra que deve ser oferecido como alimento como alvo já deslocado para a inveja ou algo semelhante ao que Lacan, intérprete de Gracián, chama de semblante" (CERQUEIRA FILHO, 2002, p. 82). ${ }^{c}$ Cabe ressaltar que o semblante, tal qual elabora Lacan no Seminário 18, não é querer se passar por ou fazer-se de, fazer semblante só é possível se o real comparece para sustentálo. Ser é só aparência de ser. Não existe palavra verdadeira. Qualquer discurso que estabelece laços entre sujeitos precisa se acercar da verdade que ele oculta e que sustenta. Não existe discurso transparente, verdadeiro, puro, pois essa ideia de perfeição é da ordem do impossível para psicanálise. É importante destacar que para psicanálise não há oposição entre verdade e o semblante, qual seja, de que o semblante é o contrário da verdade, invalidando a relação que Lacan estabelece entre verdade e semblante. Nesse sentido, a verdade é aquilo que sustenta o semblante, e é, portanto, indissociável dele. ${ }^{9}$

No material empírico consultado até o momento destaco alguns momentos em que identificamos as questões teóricas apontadas acima. Antes, porém se faz mister esclarecer que a reestruturação do Estado sob a forma republicana no Brasil na passagem à modernidade esteve, em grande parte, nas mãos dos bacharéis, que encaminhavam as mudanças administrativas e as formas de regular e controlar as relações entre o Estado e a sociedade. Em relação ao Itamaraty, não foi diferente. O Barão do Rio Branco, nomeado ministro das relações exteriores em 1902 e exercendo o cargo até sua morte em 1912.

José Maria da Silva Paranhos Júnior (Juca Paranhos) (1845-1912). Morreu aos 67 anos. Filho do Visconde do Rio Branco. Iniciou estudos na Faculdade de Direito de São Paulo em 1862, e terminou os estudos na Faculdade de Direito do Recife em 1866, pela sua vida boêmia, que incomodava o Imperador D. Pedro Il e seu pai. Durante sua juventude teve vários conflitos com Pedro II. A mais famosa delas foi o disputadíssimo cargo de Cônsul para Liverpool. Disputou este cargo com Araújo Porto Alegre e teve preterido 3 vezes seu pleito pelo imperador, para ingressar no corpo diplomático brasileiro. Em 1872 conheceu e se apaixonou por Marie Philomè Stevens, uma atriz belga, sem berço e sem instrução. Em 1873 já tinha um filho em 1875 já estava com dois filhos e um terceiro a

\footnotetext{
${ }^{9}$ Importante enfatizar que aquilo que o semblante encobre, não é a verdade, é o real. Os discursos são forma de enganar e evitar o real, que para psicanálise não é sinônimo de realidade. Por se diz que não há discurso que não seja semblante.
} 
caminho. O pai nunca reconheceu o casamento e os netos. Isto criou uma situação complicada e constrangedora até que em 1876, o imperador viaja e a Princesa Izabel assinou sua nomeação por intermédio e coação do Duque de Caxias e do Barão de Cotegipe. Assim, aos 31 anos ingressa na diplomacia. Foi para Liverpool e atuou na diplomacia de 1876 a 1879, 1893 a 1901), durante esse período fixou residência, oficialmente, na Inglaterra. Alojou sua mulher e filhos em Paris, de onde ela nunca mais retornou para o Brasil, morrendo em 1898. Tiveram, ao todo, cinco filhos. Casou-se Marie em 1890 após receber o título de Barrão em 1888. Depois de ficar de 1876 a 1901 entre Paris, Londres e Alemanha (de 1900 a 1901), foi nomeado Ministro das Relações Exteriores (entre 1902 a 1912). - Morreu em 10 de fevereiro de 1912. Sua gestão foi estratégica porque significou uma mudança de rumos na diplomacia brasileira centrada na expansão e consolidação territorial e relações comerciais externas, principalmente, com a Inglaterra e os EUA, a qual cumpriu com êxito e obteve reconhecimento nacional pelos seus feitos na condução da política externa, conduzindo com maestria os intelectuais que gravitavam ao seu redor no denominado do Círculo Rio- Branco. Teve ao seu redor uma plêiade de intelectuais ligados ao campo do direito e que compunham o que se convencionaria chamar de "República dos Bacharéis" da qual foram selecionados um grupo de intelectuais que constituíram o chamado "Círculo Rio-Branco". Nesse contexto as escolas de direito, divididas em princípio, entre São Paulo e Recife, dispunham de um poder político importante, e seus egressos foram destinados geralmente para a administração pública, participando das transformações fundamentais em sua estrutura que caracterizaram o período (SILVA, 2008). ${ }^{a}$

Manoel de Oliveira Lima (1867-1928), fez parte desse círculo de intelectuais em torno do Barão, embora tenha se formado fora do Brasil e também fora do campo do direito. Nasceu em Pernambuco no Recife em 1867, porém foi para Portugal aos seis anos. Teve sua formação realizada em Lisboa, onde realizou seus estudos iniciais no Liceu dos Padres Lazaristas de Lisboa (de 1873 a 1880), de orientação jansênica e na Escola Acadêmica de Lisboa (de 1881-1884). Completou sua formação na Faculdade de Letras de Lisboa, onde se formou em 1888. Ingressou na carreira diplomática em 1891 aos 24 anos. Oliveira Lima casou-se em 1890, por procuração, com Flora Cavalcanti de Albuquerque. Este casamento solidificou os laços de Oliveira Lima com a oligarquia pernambucana e conferiu prestígio inconteste a sua pessoa no meio social ligada a classe dominante além de facilitar sua entrada e permanência na diplomacia. Todos os autores consultados são unânimes em afirmar a extração aristocrática de Flora, inclusive com comprovação genealógica montante 
até Jerônimo de Albuquerque. A família Cavalcanti além do Engenho de Cachoeirinha também possuía um sobrado em Parnamirim, PE, onde Oliveira Lima ficava quando vinha ao Brasil. A autora explica a partir de Nobert Elias (O processo civilizador e $A$ sociedade de corte), a sua ficção e construção de sua linhagem aristocrática, assim como G. Freyre faria posteriormente. O ponto forte que vai consolidar a construção da ficção foi o casamento com Flora. Todos os irmãos de O. Lima (que era o caçula) casaram-se com membros da aristocracia pernambucana. Luiz, irmão mais velho, casou-se com Paula de Holanda Cavalcanti, irmã do Barão de Suassuna: Amália casou-se com Adolpho Accioli Wanderley, senhor do Engenho Araçú, de Barreiros, PE, formado na Faculdade de Direito de São Paulo. Maria Benedita casou-se com Pedro Araújo Beltrão, senhor do Engenho, que abandonou a carreira política como abolicionista para dedicar-se à carreira diplomática. Ligado a oligarquia Souza Leão e politicamente protegido do Barão de Lucena. O que provavelmente contribuiu para a entrada de O. Lima na carreira diplomática (MALATIAN, 2001, p. 39-50; p. 79). a Conciliou a atividade diplomática com o ofício de historiador que exerceu até sua morte em 1928. Aposentou-se precocemente em 1913 por conta de desavenças e brigas políticas que geraram conflitos graves no corpo diplomático. Tinha uma personalidade polêmica e fez muitos desafetos ao longo da sua vida profissional. Quando o Barão assume o ministério, aos 57 anos, Oliveira Lima, aos 35 anos, já fazia parte do corpo diplomático brasileiro. A despeito de fazer parte do "Círculo do Rio-Branco", mantinha uma posição de polarização e isolamento, ambígua e contraditória tanto em relação ao Barão quanto em relação a Joaquim Nabuco, que fora seu amigo íntimo e Riu Barbosa, que também pertenciam ao círculo, entre outros. Era considerado um insurgente do círculo do Barão. Segundo a feliz expressão de seu biografo Gouvêa (1976), ' tinha um destemor que beirava a imprudência. Ou como defende Forster (2011), ${ }^{a}$ o Barão e Oliveira possuíam vocações distintas. O primeiro uma vocação intelectual e o segundo uma vocação política.

O Chanceler e o historiador viviam um no outro a realização plena da vocação, que não possuíam, mas que por isso mesmo talvez desejassem mais ardentemente. Paradoxalmente, o que mais os teria afastado seria assim essa semelhança fundamental, para além das diferenças pontuais, como polos do mesmo sinal que se repelem. Como assinala Alberto da Costa e Silva. Detestavam-se mutuamente, mas é provável que cada qual, procurasse na sua a imagem do outro (FORSTER, 2011, p. 108). b

Almeida (2003), ${ }^{a}$ também procurou investigar as aproximações e distanciamentos entre o Barão e Oliveira Lima, respectivamente, no campo da história e da diplomacia. O 
autor buscou entender a construção da noção de história de ambos, em conformidade com a cultura política de sua época, e seus limites na criação de um vínculo afetivo e político posteriormente. Para Almeida, o motor das dissidências entre os dois intelectuais girou em torno das discordâncias acerca das funções a serem desempenhadas pelo diplomata dentro do Ministério das Relações Exteriores. Entretanto, encontrei na pesquisa indícios que apontam em direção diferente, ou seja, essas relações foram atravessadas por sentimentos de inveja, ressentimento e busca de reconhecimento e teve desdobramentos que vão além do confronto estritamente político. Cabe destacar que Oliveira Lima participava estritamente dos mesmos meios e das mesmas categorias de identidade e de integração social de seus pares. Pela via do casamento ingressou na rede de sociabilidade das oligarquias pernambucanas e a partir daí vinculou-se a coterie e aos círculos intelectuais importantes como a Academia Brasileira de Letras onde ingressou aos 29 anos, Instituto Histórico e Geográfico Brasileiro de Pernambuco; além de escrever para importantes jornais da época, Diário de Pernambuco, Jornal do Brasil, Estado de São Paulo, Correio da Manhã, La Prensa, jornal Argentino e revistas, The Pan American Magazine, La Revue de Genebra. Nesse sentido, seu isolamento e polarização em relação ao Barão do Rio-Branco parecem ter tido outras motivações.

Ao longo de sua carreira como diplomata e funcionário do Ministério das Relações Exteriores, Oliveira Lima perseguiu uma posição de destaque em todas as áreas de sua atuação, quer como diplomata quer como historiador. Entretanto, seu estilo personalista e polêmico causou-lhe problemas sérios no relacionamento com seus pares e no meio diplomático. O uso agressivo da palavra direta e a crítica imprudente foi uma constante no seu discurso político, principalmente nos escritos de jornal e cartas. Entendemos seu estilo como um excesso que pode ser lido como sintoma e inferimos que o rigorismo das suas posições contém um traço canônico jansenista: "Que o teu sim seja sim, que o teu não seja não" (Evangelho de S. Mateus - cap. 5, vers. 37). No episódio em que foi acusado de germanófilo narrado por Malatian (2013) é possível identificar esse traço. Quando a guerra foi declarada, em 1914, Oliveira presenciou a atmosfera de crescente intolerância, no entanto, manteve a habitual amizade com grupos de emigrados belgas pró-germânicos e escreveu para a imprensa brasileira suas opiniões sobre o conflito.

Não foi sem consequências: às intrigas atribuídas a Fontoura Xavier, ministro do Brasil em Londres, somaram-se as visitas da Scotland Yard à sua residência em consequência de denúncias sobre seu posicionamento pró-Alemanha, claramente expresso na imprensa brasileira e em situações públicas, atitude incauta para alguém 
Passagens. Revista Internacional de História Política e Cultura Jurídica

Rio de Janeiro: vol. 10, n⿳30, setembro-dezembro, 2018, p. 335-367.

residente em um país que integrava com a França o grupo dos países Aliados, situados no campo contrário. Pouco a pouco o cerco se fechou ao seu redor tornando a permanência na Inglaterra insustentável. Manteve, porém inabalável convicção germanófila, ainda que revestida de pacifismo, a despeito do crescente isolamento motivado pelo afastamento dos amigos aliadófilos (MALATIAN, 2013, p. 145). ${ }^{\mathrm{b}}$

A despeito da situação delicada manteve seu posicionamento gozosamente expresso no narcisismo alimentado por seu rigorismo jansênico.

Eu mantive-me firme. José Veríssimo afastou-se (carta dele de março a q. respondi em abril, diz G. Freyre, q. de forma evangélica). Recusa de falar na Sorbonne em set.[embr.] o (carta de Martinenche). Fui-me criando reputação de pro-germânico, ajudando portanto a cabala de Fontoura, embora disto tivera consciência. Não hesitei. Vi 1.0 ataque de Zepelins em 1.o de set.1915. Parti p[ara] Harvard em fins de set[embro]. Aí encontrei uma atmosfera furiosam.te inglesa [...]. Quando ia regressar, aviso de Kelsch. Fui p[ara] o Brasil: encontrei atmosfera de desconfiança: boatos de expulsão. Impossível voltar. [...]. Fui ao Rio (pretendia voltar p[ara] Londres e queria cultivar meus estudos históricos). Legação britânica avisa-me de q. não poderia desembarcar. Tinha havido outra denúncia (minha conf[erência] em Clark University sobre neutralidade). Artigos meus explorados $\mathrm{p}$ [ara] comprovar minhas opiniões, e rumor de q. tinha ido ao E.U. fazer propaganda germânica. Morgan foi único a tomar minha defesa. Telegrafou a Coolidge perguntando se nas minhas lições havia eu tomado atitude unneutral (LIMA, Manoel de Oliveira apud MALATIAN, 2013, p. 145). ${ }^{\circ}$

Diante dessa atitude,

As negociações diplomáticas não conseguiram evitar que fosse impedido de regressar à Inglaterra após permanência nos Estados Unidos para ministrar um ciclo de conferências em Harvard em 1915-1916. Esse fato suspendeu a vigilância sobre suas atividades pela Scotland Yard, mas nunca mais conseguiu permissão para reingressar na Inglaterra, onde ficaram sua casa e a valiosa biblioteca, igualmente exilada. O processo de auto-exílico o levou então a "estacionar" em Pernambuco, à espera do fim da guerra para tomar novo rumo, o que acabaria ocorrendo quando conseguiu se estabelecer em Washington, onde terminou seus dias em 1928. (MALATIAN, 2013, p. 145, grifo nosso). ${ }^{\mathrm{d}}$

Outro exemplo anterior a este é o necrológio ao Barão do Rio-Branco, onde presta sua homenagem, sem deixar de lembrar-se das desavenças que guardavam.

A falta de cordialidade que entre nós existia, e que nascera da mútua desconfiança que entre nós fôra semeada, nunca me impediu de reconhecer os extraordinários serviços que o eminente brasileiro teve ensejo de prestar ao seu país [...] (LIMA, 1971 , p. 1040, grifo nosso). ${ }^{\text {a }}$

Ou ainda,

O visconde do Rio Branco, que foi na política interna um verdadeiro estadista, a quem o filho muito justamente admirava procurando seguir-lhe as pegadas não desdenhava a corrupção como uma arma de governo, antes a empregava com a sem cerimônia de um Wapole, usando do seu dom de fascinação, que aliás tanto o barão do Rio Branco como Joaquim Nabuco possuíam em alto grau (LIMA, 1986, p. 190). ${ }^{\text {a }}$

E mais, 
[...] quando confiava o posto de Londres a Regis de Oliveira, que era um homem de sociedade mas por quem o próprio Barão mão professava consideração alguma, tendo-o qualificado em conversa comigo de "pedaço de asno". Para ter a sorte de que desfrutou na carreira, chegando a sub-secretário e falecendo como embaixador - na baia como elle dizia - valia a pena ser até asno inteiro. O termo empregado pelo barão offerece testemunha sufficiente do critério por que se pautam as seleções no corpo diplomático (LIMA, 1986, p. 216). ${ }^{b}$

Diante do exposto, infiro que o estilo imprudente e o "auto-exílico" de Oliveira Lima expressa uma postura atravessada por um rigor missionário alicerçado em uma estrutura psíquica narcísica que exige reconhecimento e que, como nos informa a psicanálise, não é nunca satisfeito. Tomando como base o raciocínio abdutivo indiciário, busco relacionar a estrutura psíquica, política e religiosa com a história, para desvelar os componentes políticos dos afetos e seus efeitos na formação ideológica. Assim, ressalto que os estudos de história colonial apontam um indício chave para o entendimento da construção do campo da diplomacia no Brasil, levando-se em conta o processo de rupturas e permanências culturais e políticas com Portugal a partir do século XIX. Desta feita, procuro compreender a relação entre o momento de formação do corpo diplomático brasileiro e as aplicações das noções de soberania e nacionalidade na construção do pensamento político de cunho nacional acompanhando as reflexões de Silva (2008, p. 122-123), ${ }^{b}$ quando estabelece a relação entre nação, diplomacia e história. O que procuro é estabelecer a questão apontada alhures entre a política como prudência (arte) em contradição com a percepção tomista da política como missão (vocação). Arte em contraposição a vocação. Ou seja, pensar a atuação dos monarquistas na república, o Barão e Oliveira e por prolongamento, Gilberto Freyre, como extensão da formação política no interior do "Círculo Rio-Branco". E mais, identificar nos três a ação política como arte ou missão. Nesse sentido, a ideia de herança colonial como assinala Silva $(2008)^{c}$ é fundamental. ${ }^{10}$ Temos na história colonial os aspectos de afirmação da nacionalidade através da "herança colonial" que era a prática dos

\footnotetext{
10 "Conforme defendem muitos dos autores que pensaram a construção da idéia de nação do Brasil, foi pelo viés territorial, expresso na íntima ligação com as ideias (e, portanto, cultura política) herdadas de Portugal, que se iniciou o encaminhamento das questões diplomáticas no sentido de sustentar a materialidade do Brasil enquanto território nacional. Podemos afirmar que a noção de diplomacia institucionalmente brasileira começou a ser utilizada, enquanto campo político de negociação internacional, nos anos seguintes da proclamação da independência, com a missão de fazer-se reconhecer enquanto soberana em relação à antiga metrópole. $\mathrm{O}$ envio do corpo diplomático imperial brasileiro à Europa constituiu o primeiro momento de materialização de um projeto dito 'nacional', na medida em que firmou a necessidade de se fazer enxergar no painel geral das então nações europeias como um corpo político autônomo. Este projeto, costurado pela ideia de Império-Nação referida correntemente pelos políticos da época como Reino do Brasil) e imaginada em um território de proporções continentais, foi o fomento da política internacional durante todo o período monárquico, que se estendeu pela República. Tratava-se de um projeto (enquanto organização planejada e aplicada materialmente) calcado na reconfiguração de poder central (que poderíamos chamar de Absolutista llustrado), que partilhava de ideias específicas de soberania, nutridas pelo binômio: nacionalidade e territorialidade" (SILVA, 2008, p. 123-124). ${ }^{d}$
} 
arbitramentos comuns do foro da política internacional no concerto das nações, tanto no Brasil-Império quanto no Brasil-República. Estas práticas de origens canônicas foram utilizadas por Portugal e Espanha, em momentos de disputas, na ausência de negociações satisfatórias para ambos os lados. E nestes casos, cabe destacar, apelava-se ao Papa, enquanto santidade e autoridade maior, para decisão final, irrevogável e inapelável, publicada por meio de bulas, como foi, por exemplo, o caso do Tratado de Tordesilhas (SILVA, 2008, p. 132-132). ${ }^{e}$ Reforçando essa argumentação trazemos Richard Morse (2000, p. 192) a quando aponta que as "missões" afirmavam também a ligação de enraizamento com a colonização portuguesa e encontravam em fontes primárias cartográficas, muitas vezes de origem canônica, documentos que confirmassem as defesas nos conflitos de fronteira com os vizinhos.

Diante do exposto, é plausível afirmar que existe uma continuidade dessa concepção canônica na política externa levada a cabo pelo Barão e na sua ação política o semblante (no sentido que Lacan confere) na condução dos conflitos que teve que enfrentar, inclusive entre "sua turma" no Itamaraty, com destaque para Oliveira Lima. A partir de Silva, é possível identificar que a ideia de política como missão (em oposição à política como arte) e suas implicações com o tomismo (e o neotomismo) foram aplicados e interiorizados por diplomatas ao longo do século XIX, dentre os quais, com destaque, o Barão do Rio-Branco (SILVA, 2008, p. 131). ${ }^{\dagger}$ As chamadas "missões" diplomáticas organizavam materiais e estabeleciam contatos políticos importantes a fim de orientar as falas de seus representantes em consonância com as ideias de direito referidas ao paradigma legalista $e$ preeminência desses direitos em relação aos países com quem disputava.

Essa visão de território continental e ao mesmo tempo pacifista deixou raízes e fizeram herdeiros por várias gerações; de Dom Pedro II, passando pelo Barão do Rio-Branco e pelo grupo de intelectuais (Círculo-Rio-Branco) que o acompanhavam como discípulos, Oliveira Lima, Joaquim Nabuco e Rui Barbosa; chegando a Gilberto Freyre que trabalhou constantemente com noções de conciliação (SILVA, 2008, p. 125). ${ }^{g}$

Portanto, a defesa de territórios com base na "herança colonial" é ponto-chave importante para o entendimento da missão diplomática brasileira naquela conjuntura. ${ }^{11}$

\footnotetext{
11 O episódio de entrada oficial do Brasil enquanto país independente (ou nem tanto) no quadro das relações políticas internacionais representou o momento a partir do qual se assumem os interesses considerados nacionais em torno das políticas de diálogo e afirmação da soberania territorial brasileira. Inaugurada como um projeto de nação imaginado pelas oligarquias imperiais, os símbolos deste projeto se configuraram num desejo explícito de justificativa e legitimidade. Com o maior território do continente (maior inclusive que os Estados Unidos, até a compra do Alaska em 1867), havia a necessidade de pensar o país de maneira grandiosa e magistral. Compatíveis com seu tamanho estavam às aspirações de poder e de riqueza imaginados pelo Império e, a fim de consolidá-lo, era imprescindível promover o crescimento do país, de acordo com suas possibilidades econômicas, e de afirmar seu corpo político (o reino), como representante
} 
Passagens. Revista Internacional de História Política e Cultura Jurídica

Rio de Janeiro: vol. 10, n⿳30, setembro-dezembro, 2018, p. 335-367.

Confirmando essa ideia, Oliveira Lima como diplomata-historiador afirma que "para ter uma política externa eficiente precisaria ter uma história nacional bem fundamentada" (FORSTER, 2011, p. 180). C Daí a missão levada a cabo por ele no seu ofício de historiador e na formação da sua biblioteca particular "Brasiliana" especializadíssima em documentos do Brasil colonial, além de seus estudos sobre o império, sobretudo sua obra mestra D. João VI. A ideia de "herança colonial" foi alvo das preocupações dos intelectuais que constituem o objeto desta pesquisa e destaco os esforços de Oliveira Lima, e seu "herdeiro" Gilberto Freyre na construção da identidade nacional no Brasil a partir de uma mesma matriz, qual seja a católico-ibérica. Desse modo, o princípio norteador do projeto de nação pensado para o Brasil por políticos e diplomatas do Império se prolongou nas mãos de RioBranco, Oliveira Lima e Gilberto Freyre adentrando o século XX. Segundo Mota (2010, p. 85-86), ${ }^{b}$ Freyre foi uma espécie de homem ponte entre a geração de Oliveira Lima e a sua:

\begin{abstract}
Oliveira Lima representa o fim de uma época. Época que cede passo a passo para um novo tempo, que se anuncia na figura de um jovem pernambucano a que o historiador marcaria fundamente. Trata-se do jovem Gilberto Freyre, que desde 1917 até o falecimento de Oliveira Lima em 1928, absorveu a percepção limiana e sua sensibilidade histórica [...]. Um século se despedindo do período colonial, de seu rançoso legado e construindo Estado-Nação Imperial. Eis a síntese e significado da obra e da ação de Oliveira Lima. "Já Gilberto Freyre, uma espécie de homem ponte entre o grupo geração de Oliveira Lima e o seu próprio, representa a recém chegada modernidade, ambígua, inquieta, ensaística, curiosa e algo atrasada do século XX nos seus albores.
\end{abstract}

Em Gomes (2005) podemos verificar o grau profundo de amizade, orientação e pertencimento de Freyre a uma rede de intelectuais sob a orientação de Oliveira Lima que vai introduzindo Freyre nas suas relações nacionais e internacionais e conduzindo sua carreira. Particularmente a partir da década de 1920 quando Freyre está em Columbia completando seus estudos de mestrado e Oliveira já se encontra em Washington aposentado e ministrando cursos pelas universidades europeias e organizando sua biblioteca particular, a Brasiliana. Gomes (2005, p. 21-22) ${ }^{\text {b }}$ destaca que Freyre em 1920

Dirige-se a Lima com um pedido de orientação: Tomo a liberdade de importuná-lo com meus planos de estudo e de vida" [...] A discussão do tema da tese é a questão que dá partida a uma conversa intelectual entre eles, o que evidencia o lugar que Lima vai decididamente assumindo na vida do estudante Freyre. O que importa observar é o mapeamento de temas considerados relevantes por ambos e também

\footnotetext{
fiel deste projeto. Para isto, uma intelectualidade instruída, sofisticada nas maneiras de lidar socialmente; aristocrática e em sintonia com o campo intelectual da Europa eram fundamentais. Este foi o projeto de Brasil - Império que D. Pedro II, herdeiro do trono e criado pela figura excepcional de José Bonifácio de Andrada e Silva, pensava ser o valioso projeto de futuro para as gerações seguintes. Simbolizada por políticos como José Maria da Silva Paranhos (o Visconde do Rio-Branco), Nabuco de Araújo, Barão Homem de Melo, Barão de Penedo, dentre outros, foi esta a geração que ajudou a consolidar ideias de nação e patriotismo enraizadas para muito mais além de 1889 (SILVA, 2008, 128). ${ }^{\text {h }}$
} 
Passagens. Revista Internacional de História Política e Cultura Jurídica

Rio de Janeiro: vol. 10, n⿳30, setembro-dezembro, 2018, p. 335-367.

pelo professor Harding Shepherd, que viria a ser o orientador de Freyre em Columbia. [...] O que fica evidente nessa conversa a três [...].

Além do mais,

As cartas deixam ver como ele (Lima) se sente realmente feliz com o sucesso de Freyre e como investe na sua função de apresentá-lo ao mundo político-intelectual a que pertencia. Isso irá acontecer sobretudo nos EUA, pois Lima conhece vários dos mestres de Freyre em Columbia" [...] justamente por isso é ele que escreve uma carta recomendando Freyre a Shepherd e insiste para que faça bons contatos e se beneficie do conhecimento de, por exemplo, Angel Cesar Rivas, em Nova York, e do geólogo John casper Bramer, em Stanford [...] Nesse momento, ele parece municiar Freyre de um conjunto de contatos - nomes, endereços, apresentações em vários países [...] Eles seriam um meio de Freyre fazer contatos, de ganhar visibilidade e prestigio (GOMES, 2005, p. 26). ${ }^{\circ}$

Oliveira Lima demonstra entusiasmo e orgulho com o sucesso de Freyre "Bem sabe como folgo em que se esteja fazendo conhecido e apreciado. Prepare-se para as invejas e não perca o bom humor" (Carta de Lima de 03/11/1922). Tereza Malatian (2001), b ao traçar o perfil biográfico de Oliveira Lima não só aponta a idealização construída por ele sua genealogia para pertencer à sociedade de corte, como sua atuação política na diplomacia em torno da sua relação com as coteries do Brasil e de Portugal. Como também, percebe a relação entre Oliveira e Freyre, para além da amizade, bem como as influências do contexto de formação de Oliveira Lima em Portugal no contexto das insurreições liberais em Lisboa e no Porto; a germanização de Portugal e sua influência no pensamento de Oliveira Lima e, a carreira diplomática, como extensão do seu ofício de historiador.

Desse modo, e isto é importante, embora inscrito numa outra temporalidade, Freyre se apropriou dos temas trabalhados pela intelectualidade brasileira da geração que 0 precedeu, especialmente pelos intelectuais do Círculo Rio-Branco e principalmente de Oliveira Lima, de quem se orgulhou de dizer que era "herdeiro intelectual", embora não tenha dado o devido mérito a influência teórica fundamental deste na sua obra CG\&S.

Oliveira Lima, a despeito de sua falta de habilidade com a palavra na política, no sentido que apontamos da montra ou semblante, foi um intelectual respeitado e reconhecido na academia em âmbito internacional. O título de "Embaixador intelectual" do Brasil foi concedido a Oliveira Lima pelo professor membro do Instituto Nobel, Göran Björkman, durante a visita do diplomata a Estocolmo em 1909. Recordando em suas Memórias, Oliveira alude: "Com um certo senso das realidades que mais tarde caracterizou minha propaganda intelectual do Brasil, que foi o distintivo da minha atividade diplomática [...]" (LIMA, 1986, p. 13-14). . Destarte tenha consolidado seu nome nos inúmeros foros aos quais participou, a vaidade narcísica juntamente com seu rigorismo jansênico atrapalhou sua atividade diplomática sem, no entanto, prejudicar o historiador. 
Se é verdadeiro o que de mim escreveu no suplemento do Times de Londres em 25 de junho de 1925, - o professor Harold Temperley da universidade de Cambridge, a saber que sou a maior autoridade viva em historia de Portugal e do Brasil do primeiro quartel do século XIX, devo-o sobretudo a essa plêiade de homens notáveis que me ensinaram a estudar aquela ao mesmo tempo ciência e arte (LIMA, 1986, p. 220). ${ }^{d}$

Nesse sentido, enquanto Rio Branco empreendeu com sucesso o papel proeminente de Ministro das Relações exteriores, conduzindo com maestria a política como arte. Oliveira Lima desempenhou com êxito a promoção do país inaugurando a "diplomacia cultural" abastecida por sua obra historiográfica e pelo reconhecimento internacional que conquistou. Divulgando em grandes centros acadêmicos internacionais a imagem "coesa e estável" da recém-república brasileira inserida no contexto nacional (Pernambuco) e Americano a partir das raízes ibéricas (Portugal e Espanha). ${ }^{12}$ Contudo, preliminarmente é possível inferir que o traço rigorista jansênico alicerçado no narcisismo emoldurado na e pela vanglória de mandar, fez mais desafetos do que amigos e distanciou Oliveira Lima do Brasil, levando-o ao "auto-exílio". Freyre (1968)a em Don Quixote Gordo assim expressa à imagem de Oliveira Lima por Graça Aranha, um de seus desafetos.

Desconhecido, para muitos. Caricatura do realmente foi para outros tantos. Caricatura que o apresenta, ora como glutão, ora como ambicioso ou, ainda, como invejoso. Invejoso de Joaquim Nabuco. Invejoso do Barão do Rio Branco". Lembra também a charge de Emílio de Menezes que ficou célebre: "eis em resumo essa figura estranha/tem mil léguas quadrada de vaidade / por milímetro cúbico de banha - tão ambicioso quanto gordo". Segundo Freyre, Oliveira Lima foi chamado de vaidoso por "aspirar ao desempenho de tarefas para as quais se encontra apto ou maduro, excesso de ambição? Despropósito? Indignidade? (FREYRE, 1968, p. 17-19, grifo nosso). ${ }^{b}$

\footnotetext{
12 Palestras e atuação de Oliveira Lima. Viena, 1908, conseguiu dois feitos: primeiro, que o Português fosse pela primeira vez uma das línguas faladas num congresso científico e; segundo, que o compositor barroco brasileiro padre José Maurício fosse ouvido, ao lado de grandes compositores austríacos como Haydn e Mozart, num congresso de música clássica.). 1911 - Em Paris, Sorbonne proferiu a palestra Formação Histórica da Nacionalidade Brasileira (que constitui uma grande síntese da história do Brasil) e inaugurou a cadeira de estudos brasileiros na Sorbonne. 1912 - Fez uma série de conferências na universidade de Stanford na Califórnia e depois uma turnê por 11 grandes universidades americanas a convite do professor John Casper Branner, onde ministrou palestras sobre a história luso-brasileira. Essas conferências foram editadas pela universidade e foram publicadas em espanhol traduzidas por Angel Cesar Rivas e apresentadas em português sob o título de "América inglesa e América Latina em 1914.Conferências: Universidade de Berkeley (Califórnia); Lawrence (Kansas); Chicago; Madison, Ann Arbor, Cornell, Vassar, John's Hopkins, Columbia (Nova York); Yale e Harvard. Em 1913 - Preterido para a prestigiosa missão em Londres se aposenta e retorna a Bélgica Na Bélgica, fez com que fossem criadas cadeiras de língua portuguesa nas universidades.1914-1915 - Foi acusado de germanófilo e é impedido de retornar a Inglaterra1915-1916 Dirigiu a cadeira de história da América do Sul na Harvard, EUA. 1916 - Instalou-se em no sobrado de Parnamirim e acertou com a Universidade Católica Americana a doação da sua bibiblioteca brasiliana. 1919 - Realiza conferências na Argentina sobre Panamericanismo.1920 -Deu conferências em Columbia.1921 Transfere-se definitivamente para Washington, EUA.1923 - Inaugurou a cadeira de estudos brasileiros na Faculdade de Letras de Lisboa com conferências sobre aspectos da história e da cultura brasileira. Em 1924 em 05 de fevereiro - Inaugura a Oliveira Lima Library ao público na U.C.A. Também professor honorário da Faculdade de Direito do Recife. Na doação faz duas exigências, que ele fosse o primeiro bibliotecário e que ela fosse uma biblioteca autônoma e separada na Universidade Católica. (Memórias). 1925 Ministra curso de direito internacional na universidade de Maryland (VELLOZO, 2012, p. 64-69). .
} 
Passagens. Revista Internacional de História Política e Cultura Jurídica

Rio de Janeiro: vol. 10, n⿳30, setembro-dezembro, 2018, p. 335-367.

Lima desejou ser ministro do Brasil em Londres, governador de Pernambuco e ministro das Relações Exteriores, porém não obteve êxito nesses pleitos. Freyre (1968, p. $19)^{\mathrm{C}}$ registra a imagem que ficou de Oliveira:

Oliveira Lima vem sofrendo, depois de morto, da tremenda força desmoralizante das anedotas e das caricaturas que seus inimigos conseguiram, ainda ele vivo, atuante e temível, armar em torno do seu nome e de sua pessoa: da sua obesidade - seu "calcanhar de Achiles", segundo ele próprio - fácil de ser utilizada como base de tôda uma lenda: a de sua glutoneria e de algumas das suas atitudes, por vezes impopulares na época em que ele as tomou: sua restrições ao Pan-americanismo de Joaquim Nabuco [...] suas críticas ao Barão [...], em algumas publicações estrangeiras; [...] seu pacifismo em face a Primeira Guerra; [...] seu monarquismo [...], suas ausências do Brasil e do Rio de Janeiro [...].

Sobre o exílio Freyre acrescenta, em terceira pessoa, seu lamento melancólico e implicitamente reflete sobre si mesmo ensaiando uma interpretação.

Cresceu o autor admirando um Oliveira Lima que, desde adolescente, conheceu de perto [...] um patriota, um brasileiro, aos seus olhos de menino e de adolescente exemplar, mesmo através de dos seus fracassos [...]. Mais; conheceu-o romantizado pelo exílio. Exílio voluntário, mas exílio. Exílio em pais, no inverno frio, brumoso, cinzento, em contraste com o Brasil que [...] que não soube nunca tratar brasileiro tão insigne com o calor afetuosamente materno que Oliveira Lima não só merecia como desejava. Desejava sem dizer que desejava: reprimindo seus desejos. Escondendo-os. Abafando-os. E por isso mesmo sofrendo mais do que fosse franco na expressão desse anseio de filho a vida inteira um tanto afastado do seu país; servindo-o no estrangeiro. "Longe da vista, longe do coração", diz a sabedoria popular que também insinua: "quem vai ao mar, perde o lugar". Oliveira Lima, atravessando várias vezes o Atlântico a serviço do Brasil, perdeu, na sua terra, grande parte do lugar que deveria, talvez, ter sido seu. Inconfundivelmente seu. Viu-se esquecido por muito e substituído por alguns [...] vítima de ressentimentos, de mesquinharias, de inveja e de despeito [...] por ter sido sua própria personalidade, de homem por vezes difícil [...] provocando resistências de competidores e suscitando obstáculos de conservadores a arrojos de renovador. Personalidade angulosa em vez de redonda, isto ele foi. Quixotesca. Pernambucana; os pernambucanos mais autênticos raramente se destacam como homens psicologicamente redondos ou macios. Nenhum até hoje chegou a chanceler ou à Presidência da República; fato que pode ser apenas um acidente mas talvez represente um fenômeno psicológico mais do que sociológico (FREYRE, 1968, p. 32-33). ${ }^{d}$

O uso do termo o termo "exílio" é uma referência semântica que acompanhou os discursos de Oliveira e Gilberto Freyre. As trajetórias dos atores e seus deslocamentos físicos por diversos países, com destaque à Oliveira, é uma forma de pensar sua à herança cultural da intelectualidade brasileira da virada ao século XX. Trata-se aqui de situar a política como missão. Para tal examinamos até que ponto suas obras estiveram influenciadas pelas ideias de "exílio voluntário" ou "autoexílio" associado a um pessimismo romântico. ${ }^{13}$ No caso de Oliveira a missão salvífica como historiador e diplomata a serviço do projeto civilizador romano-cristão e ibérico se expressa em suas Memórias.

13 Exílio, como indicação semântica, denota uma relação estreita com a partida, a despedida e uma espécie de necessidade imperiosa de partir. Não por acaso, o termo indica formalmente o movimento de ida daqueles 
Passagens. Revista Internacional de História Política e Cultura Jurídica

Rio de Janeiro: vol. 10, n⿳30, setembro-dezembro, 2018, p. 335-367.

Se não sou catholico praticante e meu espirito se rebela contra certos dogmas, nutro, no entanto um entimento que já defini de "catholicismo histórico". Aprecio e exalto os beneficios que a religiao christã mais que qualquer outra trouxe à civilização, e admiro a disciplina ecclesiastica que permite o cumprimento de tão sublimes feitos de abnegação e de sacrificio como, por exemplo, os dos Jesuitas, que em todo mundo emollaram suas vidas pela fé e vazaram no seculo um moldes duradouros da cultura do Brasil que sem elles teria crescia disforme e repellente. $O$ meu amigo Dom Sebastião Leme, que é um alto espirito escreveu-me uma vez que a minha tolerancia e bom humor literario escondiam amargor e que só a devoção curava d'isso, que pelo que eu, me achava à porta do templo, deveria penetrar n'elle. Respondi-lhe que não estava à porta, e sim pra ca do guarda vento, mais que para chegar até ao altar-mór era mister respeitar duvidas que eram antes crenças e que se tinham consubstanciado com a minha mentalidade. Apesar d'estas reservas eu nunca abjuraria o meu credo, da mesma forma que jamais renunciaria à minha patria, com o quanto the enxergue os defeitos e me preocupe o seu futuro [...]. Do meu sentimento religioso dei prova mais palpável doando à Universidade catholica da America a minha biblioteca de 40.000 volumes incumbindo-a de prolongar a directriz da minha acção diplomática (LIMA, 1986 p.18-19). .

A diplomacia cultural vivida como missão civilizadora por Oliveira Lima, que pensa o Brasil a partir de Pernambuco e inserido na tradição ibérica, parece ter sido seguida por Freyre. No seu diário em 1924 no Recife registra:

\begin{abstract}
Meu plano para uma publicação comemorativa do $1^{\circ}$ Centenário do Diário de Pernambuco [...]. É um plano regionalista, hispanista e americanista. Situa Recife nos vários conjuntos de que ele é na verdade essencial; o conjunto regional nordestino; o conjunto brasileiro; o conjunto hispânico; o conjunto americano. Plano, bem sei ideal. Não poderá ser realizado. Mas planejar trabalhos em termos ideais não é mal que deva ser sempre evitado. O quixotismo nunca deve ser de todo evitado. Ou de todo substituído por um realismo à la sancho (FREYRE, 1975, p. 150). ${ }^{c}$
\end{abstract}

Nessa direção, Strieder (2002) aponta que devemos prestar atenção no papel que Oliveira Lima teve na controversa (re) conversão de Freyre ao catolicismo. E chama atenção para dois depoimentos, um de Gilberto Freyre quando ainda protestante destaca sua atuação na conversão de fiéis e faz referência ao efeito de sua fala na conversão de Orlando Dantas. E o depoimento emocionado de Ariano Suassuna sobre a catolicidade de Freyre (STRIEDER, 2002, p. 112; 114-115). ${ }^{\mathrm{b}}$ Também podemos observar à ambiguidade religiosa de Freyre na declaração do Pastor Francisco Bonato Pereira do Instituto Arqueológico, Histórico e Geográfico Pernambucano.

Os fatos narrados pelo saudoso historiador Mario Ribeiro Martins, sobre Gilberto de Mello Freyre, são verídicos e foram embasados em relatórios dos missionários norte-americanos que serviam neste Estado, particularmente no Colégio Americano Batista, no Recife, onde o seu pai Alfredo Alves da Silva Freyre foi professor entre 1908 e 1938. Esses relatórios foram publicados nas Assembleias da Convenção

que, numa dada situação política de conflito e de discordância, são forçados a sair do seu país, do seu lugar de origem. Não chegando a ser exatamente extradição, mais forte e mais incisiva, definitiva e integral, nem mesmo expatriamento, o termo exílio envolve o significado entre uma escolha e uma falta de opção que traduz um sentido bastante particular. Especialmente, no que tange as análises acerca do pensamento político no Brasil, como desdobramento de um comportamento afetivo de cunho pessimista-romântico (SILVA, 2008, p. 163). 
Passagens. Revista Internacional de História Política e Cultura Jurídica

Rio de Janeiro: vol. 10, n⿳30, setembro-dezembro, 2018, p. 335-367.

Batista do Sul dos Estados Unidos. Aliás, a família de Gilberto Freyre esteve umbilicalmente ligada aos batistas por décadas. Como disse, seu pai Alfredo Freyre foi professor por mais de três décadas. Gilberto Freyre e seu irmão Ulisses também foram professores do CAB tendo sido ambos enviados à Universidade Baylor (Batista), de onde Ulisses retornou para ensinar no CAB. Gilberto Freyre e sua irmã Gasparina foram batizados na PIB Recife, pelo missionário Harvey Muirhead, que também foi diretor do CAB por mais de vinte anos até se transferir para o Seminário Batista do Sul (1930). Embora Gilberto tenha deixado a Igreja Batista, permaneceu amigo de muitos batistas, inclusive atendendo aos seus pleitos, como chefe de gabinete do Governador Estácio Coimbra (1926-1930). Gilberto Freyre estudou no CAB desde 1910 (ou 1911), colando Grau de Bacharel em Ciências e Letras, na primeira turma, cujo paraninfo foi o Embaixador Oliveira Lima (1917). Sua irmã Gasparina Freyre Costa foi membro da PIB Recife, mudando-se para a Bahia, tornou membro da IB Mares, em Salvador. Retornando o casal ao Recife, tornaramse membros da IB CAPUNGA até o fim dos seus dias. ${ }^{14}$

Sua ambivalência também se manifesta quando relata em seu diário em Nova lorque em 1921: "Não perco concertos de Bach na Catedral de São João o Teólogo. É a música que mais corresponde ao que há em mim de místico para quem o Protestantismo e o Catolicismo não há fronteiras rígidas [...]" (FREYRE, 1975, p. 54). ${ }^{d}$

Em 1977, Gilberto Freyre fez uma palestra na Comissão de Educação e Cultura da Câmara dos Deputados, em Brasília, sobre Terra, Homem e Educação. Ao final da palestra, o deputado Dayl de Almeida pediu um esclarecimento a Gilberto Freyre sobre uma frase que havia pronunciado durante a palestra, afirmando que "a Igreja Católica temporariamente estava decadente". O deputado queria saber o que Freyre queria dizer com esta frase. E Gilberto explica:

Sr. Deputado... talvez a sua maneira de ver a Igreja Católica- que eu tanto respeito - seja a de um católico... A minha maneira não é a de um indivíduo teologicamente católico. Não sou teologicamente católico. Não posso, porém, dizer que, como brasileiro, não seja católico, sociologicamente católico. Acho que todo brasileiro, mesmo quando é protestante, mesmo quando é israelita, ou maometano, ou budista, é sociologicamente católico. [...] De modo que, desse ponto de vista, sou um aculturado pela Igreja Católica, pelo catolicismo, mas teologicamente não sou católico... vendo o assunto de fora dentro... há um declínio... decadência... na ortodoxia católica em todo mundo e com reflexo no catolicismo brasileiro" (STRIEDER, 2002, p.108-109). ${ }^{\circ}$

E além do mais, Strieder chama atenção nos escritos de Gilberto Freyre para a quantidade de vezes que ele menciona os grandes místicos do cristianismo, com destaque para a mística ibérica.

Especial menção recebem, no mundo hispânico, o franciscano Raimundo Lullo, São João da Cruz, Santa Tereza de Ávila, Unamuno. Dentre os filósofos, de certa forma ligados à tradição mística, Freyre simpatiza especialmente com Santo Agostinho, Pascal, Bergson, Jacques Maritain, Péguy, Gabriel Mareei, Santayana. Causa-Ihe especial admiração a

${ }_{14}$ E-mail enviado pelo pastor Franscisco Bonato Pereira em resposta às indagações de Claudio Marcio Coelho, referentes a pesquisa de tese doutoral do PPGHIS/UFES, em 26 de agosto de 2016. 
atitude de Santayana, que abandonou inesperadamente a sua cátedra em Harvard, para viver o restante de sua vida enclausurado num mosteiro no sul da Itália. Dentre os grandes santos, Freyre mostra simpatia especial por São Francisco de Assis e por Santo António (STRIEDER, 2002, p.109).d

O projeto civilizador que Oliveira Lima vive como missão é passado e aceito por G. Freyre. Destarte ele tenha enfrentado também dificuldades, não por inabilidade com a palavra, sobretudo escrita, onde desenvolveu um estilo sedutor ou "missionário", digno de nota. Mas posto que considerado traidor pela Reação Católica levada a cabo por D. Leme nos anos 1920 e pela Ação Católica Brasileira dirigida por Amoroso Lima, que o consideraram traidor, trânsfuga, e não "perdoaram" o passado jansênico de seu pai Alfredo Freyre, e do pai intelectual Oliveira Lima, além do seu passado protestante (COELHO, 2016). ${ }^{b}$

A respeito da questão religiosa no Brasil republicano destaco em CG\&S, como Freyre se refere à entrada de estrangeiros no Brasil colônia e revela implicitamente a marca da traição na família Wanderley da qual descende pela via paterna.

A nenhum inglês nem flamengo o fato, em si, da nacionalidade ou da raça, impediu que fosse admitido na sociedade colonial portuguesa da América no século XVI. O que era preciso é que fosse católico-romano ou aqui se desinfetasse com água benta da heresia pestífera. Quase se batizasse. Que professasse a fé católica, apostólica romana... A igreja era uma espécie desinfetório ao serviço da saúde moral da colônia, um lazareto onde as almas ficavam em quarentena (FREYRE, 2006, p. 277). ${ }^{b}$

Continuando sua argumentação G. Freyre prossegue contando o caso da origem da família Wanderley e a acusação de trânsfuga do jansenismo para o papismo desde aquela conjuntura. A marca dessa traição repercutiu na disputa religiosa das primeiras décadas do século XX no Brasil republicano, atingindo a família a Freyre, sobretudo pela linhagem da avó paterna de G. Freyre, Maria Raymunda da Rocha Wanderley,

Handelmann salienta que a principal exigência para adquirir sesmarias no Brasil era professar o colono a religião católica. Seria católico Whitall ou aqui se teria ligado à Igreja antes de casar-se com a filha de Adorno; do mesmo modo que Gaspar van der lei, para unir-se pelo casamento à família Melo, em Pernambuco, teve de abraçar a religião da noiva, filha de rico senhor de engenho. Do fidalgo holandês, porém, ficaram murmurando os seus compatriotas que era homem dúbio e incerto. Não perdoaram nunca o ilustre fundador da família Wanderley no Brasil haver se bandeado para os portugueses e para o papismo (FREYRE, 2006, p. 277-278). ${ }^{c}$

Prosseguindo:

Dos Wanderleys têm saído para a vida política, para a magistratura e o sacerdócio, alguns homens ilustres, embora nenhum com características de gênio - exceção, 
Passagens. Revista Internacional de História Política e Cultura Jurídica

Rio de Janeiro: vol. 10, n⿳30, setembro-dezembro, 2018, p. 335-367.

talvez do barão de Cotegipe, um dos maiores estadistas do império. Mas este, ao que parece, com a sua pinta de sangue negro. Por outro lado poderiam colher-se exemplos numerosos, entre os Wanderley autênticos - entre os mais louros e corde-rosa -, de degenerados pelo álcool. Irregularidade pela qual chegam a ser celebrados no folclore rural brasileiro, do mesmo modo que os Albuquerques pela tendência para mentir (mitomania), os Cavalcantis [...] pelo horror a pagar dívidas e os Sousa Leão e Carneiro da Cunha pela erotomania. Nas palavras do povo: "Não há Wanderley que não beba; Albuquerque que não minta; Cavalcante que não deva" [...] Que fraqueza de caráter seria essa? A de caçador de dote? A de trânsfuga? A de ébrio? Até que ponto podemos aceitar o depoimento dos holandeses, suspeitos no assunto, desde que Gaspar foi uma espécie de Calabar ${ }^{15}$ às avessas, traindo a própria gente para colocar-se ao lado dos pernambucanos e da noiva? (FREYRE, 2006, p. 336-363). ${ }^{d}$

\section{III}

Seguindo as pistas apontadas até o momento e articulando-as aos efeitos políticos da questão religiosa no Brasil republicano expressa pela herança jansênica em Oliveira Lima e G. Freyre e a marca da traição na trajetória de ambos, acrescento as observações de Elide Rugai Bastos (1998) a e Vamireh Chacon (2006) a que destacam como autores portugueses e espanhóis incidem no pensamento de G. Freyre. Nessa linha de raciocínio temos que em seu diário em 1921 Freyre relata; "Converso com o professor De Onis [...] Ele se espanta do fato de eu não só aceitar como desenvolver uma concepção de civilização que põe o Brasil do mesmo modo que Portugal no conjunto hispânico de nações [...]" (FREYRE, 1975, p. 54). . Ou ainda: "Falo no Oxford Spanish Club. Muito aplaudido, entre goles de Port. Um grupo extremamente simpático, o dos hispanófilos de Oxford. Vejome entre eles, entre dois amores: o amor à Inglaterra e o amor à Espanha" (FREYRE, 1975, p. 110). ${ }^{\dagger}$

Chacon apresenta pistas fabulosas que remetem às raízes bem anteriores do pensamento de Gilberto Freyre em relação aos autores hispânicos e ibéricos. Estas pistas são facilmente identificadas no Diário e na obra CGS, e remete a textos poucos conhecidos de Freyre onde fica claro não só sua profunda influência do pensamento hispânico (no sentido de ibérico), assim como sua relação o pensamento teológico, particularmente de Raimundo Lúlio e Luís Vives. ${ }^{16}$

15 "O herói do Brasil Colônia, Calabar (Domingos Fernandes Calabar), que mesmo sendo militar do grupo português, abandonou sua tropa optando pelos holandeses, que melhor cuidavam dos colonos e tinham projetos de fixação na nova terra -Brasil - em vez de apenas explorar sem nada implantar" (DICIONÁRIO..., (C)2006). ${ }^{\text {a }}$

16 Raimundo Lúlio, Ramon Llull (de incerto nascimento, 1232 ou 1235, outro tanto de falecimento, 1315 ou 1316), era catalão de Maiorca nas ilhas Baleares, medieval ortodoxo, mas não muito. Luís Vives (1492 - 1540) vinha do "País Valencià," judeu cosmopolita e renascentista, heterodoxo mas não muito: Lúlio seduzido pelo conflito de certezas do cristianismo, judaísmo e Islã, sem perder de todo as dúvidas; Vives outro tanto pelas 
Passagens. Revista Internacional de História Política e Cultura Jurídica

Rio de Janeiro: vol. 10, n⿳30, setembro-dezembro, 2018, p. 335-367.

Quanto ao seu iberismo vejamos:

Se pertenço, como possível escritor e como possível antropólogo [...] antes à forma ibérica de escritor e de analista do Homem que qualquer outra, suponho que o seja - se de fato sou - por direito tanto de quem nasceu ibérico como de quem conquistou essa sua condição ibérica em plenitude e talvez em profundidade (FREYRE, 1968, p. 175). ${ }^{e}$

Em relação à inspiração teológica

Gilberto Freyre recorre explicitamente a Raimundo Lúlio e Luís Vives, quando quer revelar as fontes das suas inspirações metodológicas humanistas mais profundas, muito além das convencionais da antropologia, sociologia e história social, nas quais fora treinado nas universidades de Baylor e Columbia nos Estados Unidos, na Inglaterra a de Oxford, em bacharelado, mestrado e inícios de inconcluso doutoramento (CHACON, 2006, p. 3). b

Inclusive Chacon faz referência que em Freyre o intra-histórico é a existencialidade e o inter-histórico mulçumano é de especial importância para o catolicismo ibérico, pois segundo ele Raimundo Lúlio foi desde o século XIII, um traço de união entre o cristianismo e o islamismo. E nesse sentido, não podemos esquecer as contribuições árabes e mulçumanas reconhecidas e proclamadas por Freyre desde CG\&S. E que este destaca que "entre as inspirações mouriscas, a mística de Lúlio influenciou inclusive Baltasar Graciàn da qual Lúlio foi predecessor" (FREYRE, 1959, p. 100, grifo nosso). ${ }^{a}$ Cabe ressaltar, que a leitura que Freyre faz de Gracían se dá em outro registro, ou seja, da perspectiva da conciliação, do equilíbrio dos antagonismos, tomista, que critico a partir de Lacan que preserva a contradição (semblante) e Cerqueira Filho que lê Gracían pela ótica da política como arte e não como missão.

dúvidas de Erasmo, sem perder as certezas básicas judaicas, às quais veio a assumir após nascimento de cristão-novo. Lúlio procurou conciliar fé e sentimento, Vives ciência e arte, duas grandes contribuições, até sistemáticas, à cultura ocidental e mundial. Lúlio era mediterrânico universal, trafegando entre a Catalunha e o Norte da África em auto-consignadas missões de dialogo para aproximar cristãos, judeus e muçulmanos. Vives foi europeísta universal, professor universidades de Louvain e Oxford, vindo a falecer em Bruges, contemporâneo do português Damião de Góes de longas permanências na Antuérpia e Louvain flamengas. Damião de Góes e Vives foram ibéricos amigos pessoais de Erasmo, seus destinos se cruzaram diversas vezes. O precursor ecumenismo de Raimundo Lúlio destaca-se em O livro do gentio e dos três sábios sobre o encontro de teólogos cristão, judeu e muçulmano com o peregrino em busca da verdade. As contradições daquelas teorias são apresentadas numa dialética mais de complementaridades, que de antagonismos. Também Lúlio intentou uma "Suma theologica et philosophica" dispersa e reconcentrada na Ars compendiosa da Ars demonstrativa e Ars interpretativa em Ars universalis, sintetizável em Ars brevis. Nelas ele retoma, amplia e aprofunda a dimensão da intuição, enquanto seu contemporâneo Tomás de Aquino enfatizava o raciocínio e o coetâneo Roger Bacon privilegiava a experiência. A questão dos universais, vindo a Guilherme Ockham, e a verdade (pela diversidade dos níveis da razão e da fé) em Averróes, Lúlio as resolve pela intuição da "sapientia cordis" agostiniana, esclarecendo as categorias lógicas aristotélicas, na sua Ars magna. Daí a alcunha de Raimundo Lúlio, "Doctor illuminatus". Lúlio fez até incursões na crítica política, inclusive eclesiásticas, nas alegorias do seu Livro dos animais (Llibre de les bésties) (CHACON, 2006, p.1-2, grifo nosso). ${ }^{\circ}$ 
Temos então que Bastos $(1998)^{b}$ concentra-se no pensamento hispânico da geração de 1898 (Ganivet, Unamuno e Ortega y Gasset) e não percebe o grau da influência do pensamento religioso de Raimundo Lúlio e Luis Vives, ou seja, da teologia política na no pensamento de Freyre. Entretanto, Chacon, que aponta e valoriza a influência dessa matriz em Freyre, não relaciona, ao menos neste texto, a vinculação deste ao projeto civilizatório cristão tomado como missão, por seu mentor intelectual, Oliveira Lima, e o prolongamento deste projeto em Gilberto Freyre. Desta feita, relacionamos esse argumento à Gracián: "As coisas não passam pelo que são, mas pelo que parecem". "Valer e saber mostrar é valer duas vezes". Tal é o sentido de "parecer" em política, Assim, temos que:

O disfarce não é exclusivamente um esconder-se na invisibilidade ou na ocultação, mas também uma via de escape do discurso político [...] fora do lugar do narcisismo e do perfeccionismo, longe de qualquer idealização, o herói deve mais fazer desejar do que excitar o gozo que sustenta a inveja, na expressão de Gracián. Trata-se de uma política anti-absolutista, por excelência. A vã glória de mandar ri da vanglória de mandar". (CERQUEIRA FILHO, 2002, p. 85-86). ${ }^{\text {d }}$

E, como aponta Gracían em um de seus aforismas, "só a virtude basta a si mesma. Vivo o homem, torna-se amorável, morto, memorável".

Isto posto, podemos inferir que o Barão realizou a política como arte e O.Lima, imprudente ao falar demais, não soube fazer o semblante. Termina seus dias isolado, melancólico, magoado, ressentido e "exilado" do Brasil. Significativo é essa parte do seu testamento.

[...] será única e universal herdeira de toda a minha herança a Universidade Católica da América, com sede em Washington D.C, Estados Unidos da América, á qual já fiz em vida doação da minha biblioteca, com o seguinte encargo e fim expresso de custear e manter uma cadeira, de língua portuguesa e história literária e econômica de Portugal e Brasil, bem como, se sobrar, de distribuir subsídios entre quaisquer estudantes pobres, sem distinção de nacionalidade nem de cor, que cultivarem com zelo essas matérias, a juízo da respectiva congregação universitária. Determino que meu corpo descanse onde ocorrer meu falecimento, sendo sepultado ou cremado de preferência, se minha religião não o vedar [...] Como epitaphio escolho somente: aqui jaz um amigo dos livros, sem indicaçao de nome [...] Também quero que nenhuma homenagem póstuma me seja feita no meu país ou fora dele [...] (LIMA, 1986, p. 254)

O Barão, virtuoso, foi laureado em vida e na morte. Seu falecimento ocorreu em 10 de fevereiro de 1912 quando pelas ruas da cidade do Rio de Janeiro, em especial nos arredores do Itamaraty, concentrava-se uma multidão de desconhecidos, gente de todas as classes sociais, misturados entre si, conforme relatado pelos jornais as notícias que davam conta do falecimento daquele que foi enunciado como um dos mais destacados 

na vida e na morte.

Havia uma identificação com a sua figura como patriota - representante do povo, consciente e responsável do seu papel de intelectual, caracterizado pela sua erudição e pelo pragmatismo político. Aspectos que o qualificavam capaz de "defender a pátria", materializando uma postura de rigor, seriedade, compromisso e superação. Significados estes compatíveis com a noção de "ordem e progresso" que se pretendia difundir, para além da realidade material do país (SILVA, 2008, p. 149). ${ }^{\mathrm{j}}$

Gilberto Freyre é o mais ambíguo dos três, seu percurso até CG\&S foi marcado por conflitos e contradições mais da ordem da emoção do que da razão, como também foi o de Oliveira Lima. Segundo indícios presentes em fragmentos de cartas, fontes secundárias e escrita autobiográfica, Freyre revela também angústia e mal-estar. O desafio internalizado como missão salvífica de tornar-se um dos "homens fortes e habilitados a reformar o país"; o racismo experimentado no exterior por ser mestiço; o não pertencimento à estética ariana que tanto admirava; a fantasia de ser um "menino de engenho" e a vanglória de mandar, atormentaram o jovem Freyre. Esses conflitos invadem o plano teórico de forma contraditória e a narrativa mitopoéitca da criação da civilização luso-brasileira nos trópicos recalca o sofrimento (pathos). Freyre formula na dialética da construção narcísica entre o eu ideal e o ideal do eu, o lugar a partir do qual queria ser visto. Ao descrever o ethos brasileiro revela o sofrimento impingido pelo colonizador (explorador). Entretanto, afetado pelo ideal de perfeição tomista expresso também no seu narcisismo e idealização do pater famils; constrói uma interpretação que promove a integração e a conciliação dos conflitos. Entretanto, todo o recalcado pode ser novamente retomado e reutilizado numa espécie de

17 "Com o passamento do Barão do Rio Branco, perde o Brasil um dos seus mais diletos filhos e um dos seus mais dedicados servidores. A República, principalmente, deve-Ihe os mais relevantes e inestimáveis serviços" (A República, 10 de fevereiro de 1912). "A morte do Barão do Rio Branco, nesse momento, representa um desastre para a Nação, porquanto, agora, mais do que nunca, eram necessários os seus serviços. As próprias nações estrangeiras, os próprios jornais argentinos, que não olhavam o Sr. Barão do Rio Branco com bons olhos, proclamam os seus méritos de estadista e de bom patriota" (O Baluarte, 11 de fevereiro de 1912). "Sua obra foi enorme e grandiosa. Ele teve duas vidas: a do jornalista de talento que se fez cônsul e a do cônsul que se transformou no maior dos brasileiros pelo seu desinteressado amor à pátria, e no maior dos diplomatas contemporâneos pelo seu alto espírito, pela alta compreensão da função que exercia. Ele foi o dilatador do Brasil alargando-o e aumentando-o em terras, graças ao seu engenho, sem um leve ataque à justiça e ao seu direito" (Gazeta de Notícias, 11 de fevereiro de 1912). "A multidão subia e descia as escadas do Itamarati como levada ao peso de uma mudez angustiosa - e eram mais os olhos magoados, que exprimem o doloroso sentimento dessa perda que avassala o Brasil e a fraternidade sul-americana. No vasto salão onde cisma a tristeza de amigos e filhos do eminente estadista e por onde peregrinava o pezar do povo brasileiro, nós também estivemos um momento, olhando o catafalco, em torno do qual seis brandões acessos derramavam as suas lágrimas de cêra. Mas o aspecto profundamente impressionante, que nos feria os olhos, era demasiado forte para nós, que sempre veneramos no grande ministro o mais fiel, o mais seguro, o mais vigilante guarda da pátria, que ele estremeceu, sobretudo neste mundo. E, alquebrado também pele dor do grande infortúnio, afastamo-nos dali, trazendo a impressão da pena alheia, que se veio juntar à nossa" ( $A$ Imprensa, 12 de fevereiro de 1912). 


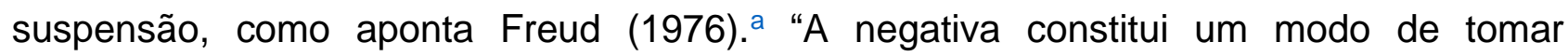
conhecimento do que está reprimido [recalcado]; com efeito, já é uma suspensão da repressão [do recalque], embora não, naturalmente, uma aceitação do que está reprimido [recalcado]" (FREUD, 1976, p. 296). ${ }^{b}$ A negação marca a operação do recalque e seu correlato, o retorno do recalcado. Nesse sentido, o recalque do pathos na interpretação freyriana não é uma operação conspiratória ou maniqueísta, mas um efeito. Não temos que procurar por de trás do enunciado aparente um sentido oculto que nos conduziria a uma verdade absoluta, ${ }^{18}$ sabemos com a psicanálise que qualquer linguagem é sempre limitada. Avisados disso, evitamos a armadilha de pensar o verdadeiro e o falso em si, mas um movimento dialético de velamento-desvelamento, onde a marca do real, que não é a realidade, se apresenta como a impossibilidade de tudo mostrar ou tudo esconder.

Diante disso, inferimos que o sucesso de CG\&S, a despeito da monstruosidade da colonização, produziu efeito positivo na nossa identificação com a fantasia de perfeição expressa no ideal de pureza tomista. O gozo provocado pelo olhar de aprovação do nosso algoz reifica o padrão de obediência e submissão evocado por Freyre por meio do catolicismo romano como cimento ideológico que apaziguou as contradições e violências do processo colonizador. A grande questão é que o reprimido sempre retorna e exige o reconhecimento de sua existência causando dor e sofrimento.

Sustento que Gilberto Freyre não escreve apenas um ensaio fabuloso, mas também as suas íntimas memórias. O registro estético, visual e literário no qual a imaginação ocupa um lugar importante é a sua marca, expressão da sua singularidade e subjetividade reveladora da complexa relação entre pathos, cultura e subjetividade. Destaco aí as influências do romantismo alemão e suas repercussões no romantismo inglês de Walter Pater (1910), ${ }^{a}$ no romantismo católico de Oliveira Lima e, sobretudo em Freyre. "Venho lendo todo o Pater - o Pater que li ou reli quase todo em Oxford, ambiente ideal para ler-se Pater. Pater e Newman. Tenho um retrato de Newman no meu quarto [...]" (FREYRE, 1975, p. 135, grifo nosso). ${ }^{9}$ Importante notar que John Henry Cardeal Newman foi um sacerdote anglicano inglês convertido ao catolicismo, posteriormente nomeado cardeal pelo papa

\footnotetext{
18 Entendemos que a verdade não deve ser procurada por trás das aparências. O que se mostra é sempre ilusório, cativo que se encontra das evidências que o corrompem. Ao mundo das ideias, lugar das verdades claras e distintas, opôs-se a retórica sofista. E foi a partir dessa polarização que pôde ser promovida uma viragem, na história da filosofia, dos temas ligados inicialmente à natureza (aos quais se dedicaram os filósofos pré-socráticos) para o tema do homem (antropologia), e com eles levantaram-se as primeiras questões da filosofia da linguagem.
} 
Leão XIII em 1879. E foi beatificado no dia 19 de setembro de 2010 pelo Papa Bento XVI. Seguindo essa reflexão é Roberto Romano (1981, p. 99-100)a quem afirma:

\begin{abstract}
No discurso romântico acentua-se o perfil da Igreja católica, a portadora do Eterno, nova fundadora do mundo. As críticas que desde Pascal, desde Voltaire dirigiramse contra a Companhia de Jesus, Novalis responde com sua apologia: "Esta sociedade será eternamente o modelo (Muster) de toda sociedade" e experimentará "uma expansão infinita bem como uma duração eterna". A política romântica notabilizou-se, assim, por apresentar este traço comum: a justificação da Igreja como modelo para toda a sociedade, única maneira de superar o radicalismo jacobino e desordenado, fruto da Reforma e da impiedade moderna. De Maistre, De Bonald, Lammenais, Donoso Cortés, todos estes pensadores elaboraram uma doutrina que convergiu no foco do romantismo alemão.
\end{abstract}

A cadeia associativa por meio da circularidade de ideias permite uma interpretação da apropriação realizada por Freyre de elementos da mimesis romântica do idealismo alemão e inglês que alimentaram seu conservadorismo romântico católico. Além da rede de sociabilidade formada por sua coterie e, particularmente, por Oliveira Lima, registram indícios que causaram angústia no percurso salvífico empreendido por Freyre em busca do menino perdido a procura de filiação, de assujeitamento. Às voltas com o fantasma do Pai amedrontador, autoritário ausente/degradado do senhor do engenho que descreveu em CG\&S; Freyre procurou tanto na obra quanto na vida, conciliar seu passado familiar à fantasia de "menino de engenho" personificado no autoritarismo afetivo (CERQUEIRA FILHO, 2005 $)^{19}$ de querer ser senhor de engenho, desejoso de poder e vanglória de mandar. Assim como desejou também ser um intelectual renomado e reconhecido. Ao se colocar no lugar idealizado de pai fundador do Brasil recorre à nostalgia do pai perdido, deixado do outro lado do Atlântico.

A obra CG\&S está povoada de fantasmas. Ao mirar a composição étnica da população brasileira com olhos de conciliação, como um quadro pintado para enxergar a realidade da janela da sua subjetividade narcísica, sua interpretação mitopoiética produz efeitos políticos no sentir da formação social brasileira. Ao se colocar como Pai do Brasil Freyre toma como missão o desejo do Outro e se submete ao colonizador-explorador. Nesse sentido, CG\&S é um prolongamento da diplomacia cultural inaugurada por Lima por meio de sua missão civilizatória de levar a imagem do Brasil coeso e integrado na sua multiplicidade e, portanto, confiável aos olhos do colonizador. Ao cunhar o conceito de equilíbrio dos antagonismos, o mestre de Apipucos acaba por teorizar sobre a prática do favor. Ao priorizar o ethos desde a "herança colonial", ofereceu ângulo para pensar as

\footnotetext{
${ }^{19}$ Fantasias de poder e autoridade contida nas emoções inconscientes com permanências culturais de longa duração.
} 
relações pessoais no Brasil fora da contradição e da monstruosidade do processo colonial. Assim, talvez inconscientemente, ajuda a bloquear a concepção ideológica de uma "sociedade de indivíduos" apoiada na tradição do pensamento burguês na passagem à modernidade. Nesse sentido, o percurso epistemológico de Freyre afetado pelo ideal de perfeição tomista denegou a tensão existente entre a ideologia do favor e o liberalismo implicando no recalcamento da concepção jurídica de lei no imaginário social brasileiro. Eis a violência em ocultar a violência! A ignorância simbólica da lei resulta de uma complexa operação, onde incidem a carência da figura paterna ou a presença de uma figura paterna degradada.

A guisa de conclusão, ressalto que a dimensão do real envolvido na relação entre o semblante e a verdade, fora do lugar do narcisismo e do perfeccionismo, tão caro a O. Lima e a G. Freyre, exige afastar a idealização do herói que excita o gozo e sustenta a inveja. E assim, abre caminho para o ser reconhecido e se reconhecer, não mais a partir de uma potência exploradora nos marcos da insuficiência imunológica psíquica do gozo sem limite como expressão trágica do recalque. Nessa direção a contribuição destas reflexões é destacar os efeitos dessa complexa operação na epistemologia da teoria social brasileira. Entendemos que este é um caminho profícuo para que possamos mais fazer desejar e encontrarmos no Nome-do-Pai o lugar do desejo do filho.

\section{Referências}

ALMEIDA, Paulo Roberto. O Barão do Rio Branco e Oliveira Lima: Vidas paralelas, Itinerários divergentes. In: CARDIM, Carlos Henrique; ALMINO, João (Org.). Rio Branco, América del Sur y la Modernización del Brasil. Rio de Janeiro: EMC, 2003. p. 241-299. ª

BARTHES, Roland. Repercussão de Gilberto Freyre no Estrangeiro. In: FREYRE, Gilberto et al. Gilberto Freyre: sua ciência, sua filosofia, sua arte. Rio de Janeiro: José Olympio, 1962. ${ }^{a}$

BASTOS, Elide Rugai. Os autores brasileiros e o pensamento hispânico. In: ENCONTRO ANUAL DA ANPOCS, 22., 1998, Caxambu, MG. Anais... Caxambu: ANPOCS, 1998. p. 124. ${ }^{a, b}$

BERLINCK, Manoel Tosta. Psicopatologia Fundamental. São Paulo: Escuta, 2000. a, b

BERLINCK, Manoel Tosta et al. Esquizofrenia e Miscigenação. Revista Latinoamericana de Psicopatologia Fundamental, v. 4, n. 4, p.11-29, dez. 2001. ${ }^{a}$

CALLIGARIS, Contardo. Hello Brasil! Notas de um psicanalista europeu viajando ao Brasil. São Paulo: Escuta, 2000. ${ }^{a}, \mathrm{~b}, \mathrm{c}$ 
CERQUEIRA FILHO, Gisálio. A ideologia do favor \& a ignorância simbólica da lei. Rio de Janeiro: CEUEP, 1993. ${ }^{a, b, c}$

CERQUEIRA FILHO, Gisálio. Olho grande ou o olhar da inveja na política. In: e excesso: reflexões sobre lei e política. Porto Alegre: SAFE, 2002. p. 77-86. $\overline{\text { a, b, c, d }}$ . Édipo

CERQUEIRA FILHO, Gisálio. Autoritarismo afetivo: a Prússia como sentimento. São Paulo: Escuta, 2005. ${ }^{\mathrm{a}}$

CERQUEIRA FILHO, Gisálio. Sérgio (modernista) Buarque de Holanda em "Viagem a Nápoles". In: COLÓQUIO INTERNACIONAL SOBRE O MÉTODO CLÍNICO, 2009, São Paulo. Anais... São Paulo: FECAP, 2009. ${ }^{a}$

CHACON, Vamireh. Lúlio e Vives: duas fontes catalãs de Gilberto Freyre. Instituto Brasileiro de Filosofia e Ciência "Raimundo Lúlio" (Ramon Llull), São Paulo, 2006. Disponível em: http://www.ramonllull.net/boletim/marco2006/luliovives1.pdf. Acesso em: 12 abr. 2018. ${ }^{\text {a, b, c }}$

COELHO, Cláudio Marcio. Religião e História: Em nome do pai: Gilberto Freyre e Casa Grande \& Senzala. Um projeto político salvífico para o Brasil (1906-1933)?. 2016. Tese (Doutorado)-Programa de Pós-Graduação em História, Universidade Federal do Espírito Santo, Vitória, 2016. ${ }^{\text {a, b }}$

DAIX, Pierr. Braudel. Paris: Flammarion, 1995. ${ }^{a}$

DICIONÁRIO INFORMAL. Calabar. C2006. Disponível em: http://www.dicionarioinformal.com.br/calabar/. Acesso em: 25 jul. 2017. ${ }^{a}$

FORSTER, Maria Theresa Diniz. Oliveira Lima e as relações exteriores do Brasil: o legado de um pioneiro e sua relevância atual para a diplomacia brasileira. Brasília: Fundação Alexandre de Gusmão, 2011. a, b, c

FREUD, Sigmund. A negativa. In: SALOMÃO, Jayme (Org.). Obras Psicológicas Completas de Sigmund Freud. Rio de Janeiro: Imago, 1925/1976. v.19. Edição Standard Brasileira. a, b

FREUD, Sigmund. Neuroses de transferência: uma síntese. Rio de Janeiro: Imago, $1914 / 1987 .^{a}$

FREYRE, Gilberto. Casa-grande \& Senzala. Rio de Janeiro: Maia e Schmidt, 1933. ${ }^{a}$

FREYRE, Gilberto. A propósito de Frades. Salvador: Progresso, 1959. ${ }^{a}$

FREYRE, Gilberto. Oliveira Lima, Don Quixote Gordo. Recife: Universidade Federal de Pernambuco, 1968. ${ }^{a, b, c, d, e}$

FREYRE, Gilberto. Tempo morto e outros tempos: trechos de um diário de adolescência e primeira mocidade, 1915-1930. Rio de Janeiro: Olympio, 1975. a, b, c, d, e, f, g

FREYRE, Gilberto. Casa Grande \& Senzala. ed. 51. São Paulo: Global, 2006. ${ }^{\text {a, b, c, d }}$

GINZBURG, Carlo. Mitos, emblemas e sinais: morfologia e história. São Paulo: Cia das Letras, 1989. ${ }^{a}$ 
GOMES, Ângela e Castro (Org.). Em família: a correspondência de Oliveira Lima e Gilberto Freyre. Campinas, SP: Mercado das Letras, 2005. ${ }^{a, b, c}$

GOUVÊA, Fernando Cruz. Oliveira Lima: uma biografia. Recife: Instituto Arqueológico, Histórico e Geográfico Pernambucano, 1976. 3 v. ${ }^{a}$

LACAN, Jaques. O Seminário: de um discurso que não fosse semblante. Rio de Janeiro: J. Zahar, 2009. livro 18. ${ }^{\mathrm{a}}$

LIMA, Manoel de Oliveira. Obra Seleta. LIMA SOBRINHO, Barbosa (Org.). Rio de Janeiro: Instituto Nacional do Livro, 1971. ${ }^{a}$

LIMA, Manoel de Oliveira. Memórias: (estas minhas reminiscências...). 2. ed. Recife: FUNDARPE, 1986. Coleção Pernambucana. ${ }^{a, b, c, d, e, f}$

MALATIAN, Tereza. Oliveira Lima e a construção da nacionalidade. São Paulo: FAPESP, 2001. ${ }^{a, b}$

MALATIAN, Tereza. "Não me atemorizou a pecha de germanófilo": a Grande Guerra nos diários de Oliveira Lima (1917-1918). Dimensões, v. 31, p. 137-158, 2013. a, b, c, d

MOTA, Carlos Guilherme. Oliveira Lima e a nossa formação. In: História e contra história: perfis e contraponto. São Paulo: Globo, 2010. p. 83-115. a, b

MORSE, Richard. O espelho de Próspero: cultura e ideias nas Américas. São Paulo: Cia das Letras, 2000. ${ }^{\mathrm{a}}$

NEDER, Gizlene. Iluminismo jurídico-penal luso brasileiro: obediência e submissão. Rio de Janeiro: Tavares Bastos, 2000. ${ }^{a}$

NEDER, Gizlene. Assistência e responsabilidade parental do Estado no Brasil: entre o dever e a caridade. In: SIMPÓSIO NACIONAL DE HISTÓRIA, 22., 2003, João Pessoa. Anais... João Pessoa: ANPUH, 2003. CD-ROM. ${ }^{a}$

NEDER, Gizlene. Duas margens: ideias jurídicas e sentimentos políticos no Brasil e em Portugal na passagem à modernidade. Rio de Janeiro: Revan: FAPERJ, 2011. Com a colaboração de Gisálio Cerqueira Filho. ${ }^{a, b, c}$

NEDER, Gizlene. As reformas políticas dos homens novos: (Brasil Império: 1830-1889). Rio de Janeiro: Revan, 2016. ${ }^{a}$

NEDER, Gizlene; CERQUEIRA FILHO, Gisálio. Ideias Jurídicas e Autoridade na Família. Rio de Janeiro: Revan, 2007. a, b

PATER, Walter. The child in the house. In: Miscellaneous studies. London, MacMillan and Co., 1910. p. 172-196. ${ }^{a}$

ROMANO, Roberto. Conservadorismo Romântico: origem do totalitarismo. São Paulo; Brasiliense, 1891. ${ }^{a}$ 
SILVA, Daniella Amaral Diniz da. Alteridade e ideia de nação na passagem à modernidade: O Círculo Rio Branco no Brasil Ubique Patriae Menor. 2008. Dissertação (Mestrado em História)-Universidade Federal Fluminense, Niterói 2008. a, b, c, d, e, f, g, h, i, j

SCHORSKE, Carl. Viena fim-de-siècle: política e cultura. São Paulo: Cia das Letras, 1988 . $^{a}$

STRIEDER, Inácio. Religiosidade em Gilberto Freyre. Perspectiva Filosófica, v. 9, n. 18, p. 105-118, jul./dez. 2002. a, b, c, d

TANNENBAUM F. Introduction. In: FREYRE, Gilberto. The mansions and the shanties. London: Weidenfeld and Nicolson, 1963. ${ }^{a}$

VELLOZO Julio César de Oliveira. Um Dom Quixote gordo no deserto do esquecimento: Oliveira Lima e a construção de uma narrativa da nacionalidade. 2012. Dissertação (Mestrado em Filosofia) - Instituto de Estudos Brasileiros, Universidade de São Paulo, São Paulo, 2012. ${ }^{\text {a }}$

ZIZEK, Slavoj. Quando a inveja vira ódio. Folha de São Paulo, São Paulo, 31 jan. 2016. Folha llustríssima, p. 1. ${ }^{\text {a }}$ 